\title{
MASTER
}

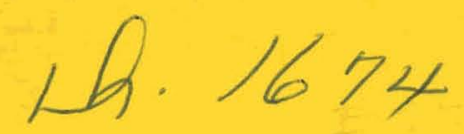

DOE /NASA CONTRACTOR

DOE/NASA CR-161494 REPORT

\section{SOLAR ENERGY SYSTEM PERFORMANCE EVALUATION - SEASONAL REPORT FOR CONTEMPORARY NEWNAN, NEWNAN, GEORGIA}

Prepared by

IBM Corporation

Federal Systems Division

150 Sparkman Drive

Huntsville, Alabama

Under Contract NAS8-32036 with

National Aeronautics and Space Administration

George C. Marshall Space Flight Center, Alabama 35812

For the U. S. Department of Energy

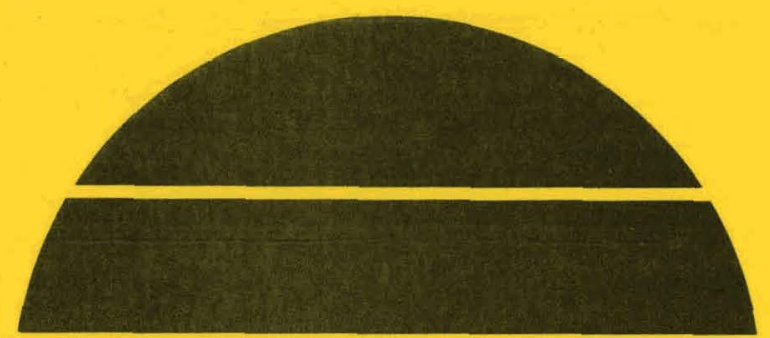

\section{U.S. Department of Energy}




\section{DISCLAIMER}

This report was prepared as an account of work sponsored by an agency of the United States Government. Neither the United States Government nor any agency Thereof, nor any of their employees, makes any warranty, express or implied, or assumes any legal liability or responsibility for the accuracy, completeness, or usefulness of any information, apparatus, product, or process disclosed, or represents that its use would not infringe privately owned rights. Reference herein to any specific commercial product, process, or service by trade name, trademark, manufacturer, or otherwise does not necessarily constitute or imply its endorsement, recommendation, or favoring by the United States Government or any agency thereof. The views and opinions of authors expressed herein do not necessarily state or reflect those of the United States Government or any agency thereof. 


\section{DISCLAIMER}

Portions of this document may be illegible in electronic image products. Images are produced from the best available original document. 
This report was prepared to document work sponsored by the Unlted States Govarnent. Nelther the Unfted States nor 1 ts agents the Unfted Statas Dapartment of Energy, the United States Nar1onal Acronaut1cs and Space Adminlstratlon, nor any fedaral employees, nor ang of thair contractors, subcontractors or the1r exployean, hike any warranty, express or Implled, or asaure any legel liabllity or resporstb1l1ty for the accuracy, cotupleteness, or issafulness of any informat1on, apparatus, product or procnes diaclosed, or represent that 1ts use would not infringe privataly owned rights. 


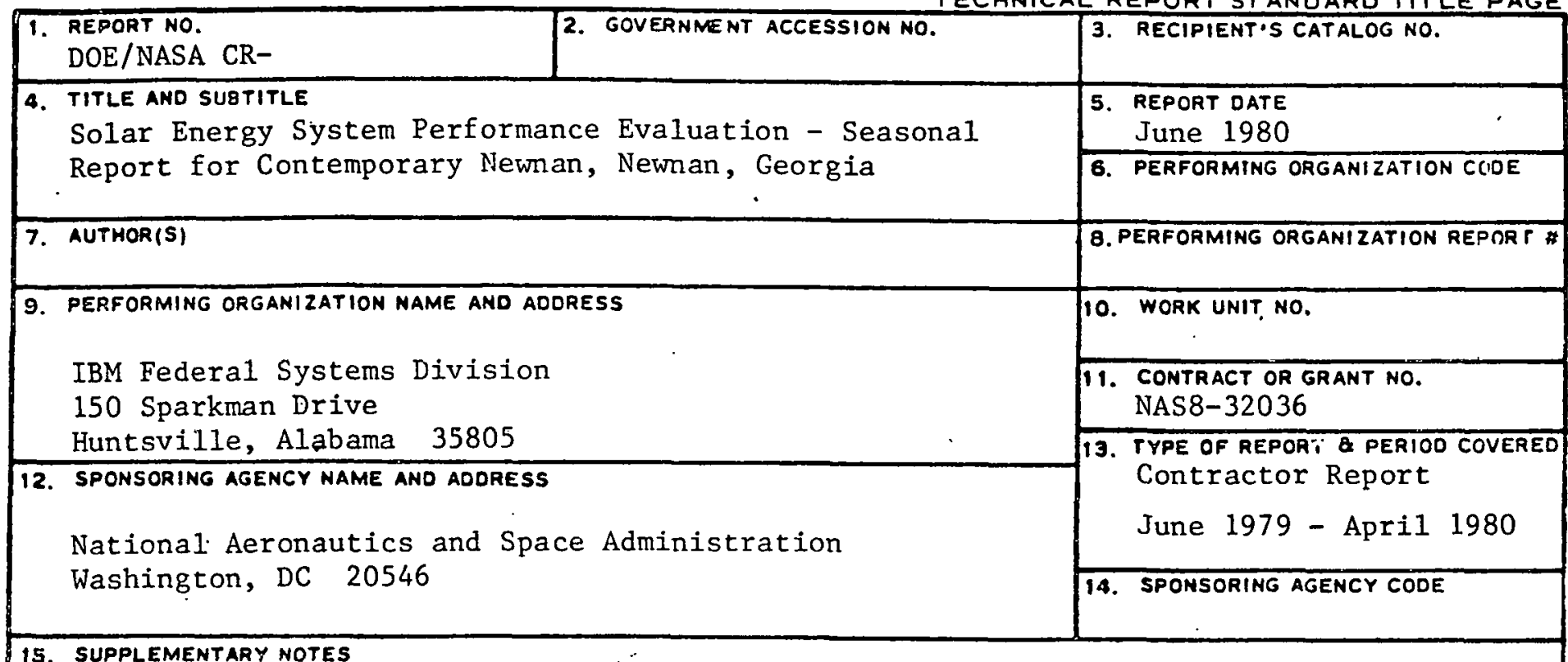

This work was done under the technical management of Mr. Cecil W. Messer, George C. Marshall Space Flight Center, Alabama.

19. AGSTRACT

This report developed for the George C. Marshall Space Flight Center as a part of the Solar Heating and Cooling Development Program funded by the Department of Energy is one of a series of reports describing the operational and thermal performance of a variety of solar systems installed in Operational Test Sites. The analysis used is based on instrumented system data monitored and collected for at least one full season of operation. The objective of the analysis is to report the long-term field performance of the installed system and to make technical contributions to the definition of techniques and requirements for solar energy system design.

The Contemporary Newnan Solar Energy System was designed by Contemporary Systems, Incorporated, Jaffrey, New Hampshire, to provide 60 percent of the space heating and domestic hot water (DHW) for a two story residence located in Newnan, Georgia. The system consists of fourteen Contemporary System Series V warm air collectors (392 square feet), a 328 cubic foot rock bin thermal storage containing 1 to $1 \frac{1}{2}$ inch diameter stones, an air handler, heat exchangers, an 80-gallon DHW preheat tank, controls, associated plumbing and air ducting. Auxiliary heating is provided by an electric heat pump supplemented by electric resistance heaters when outdoor temperatures drop below 15 degrees fahrenheit. A 40-gallon electric hot water tank is supplied water through the 80 -gallon preheat tank. The system has six modes of operation. This report includes the system description; typical system operation; system operating sequence; performance assessment; system performance; collector array, storage, hot water and space heating subsystem performance; operating energy; energy savings; and maintenance. Page 51 has the summary and conclusions discussions of this Solar Energy System which hecame operatiopal April. 1979. \begin{tabular}{l|ll} 
17. KEY WOROS & 18. OISTRIBUTION STATEMENT UC-59C
\end{tabular} Unclassified-Unlimited

\section{-}

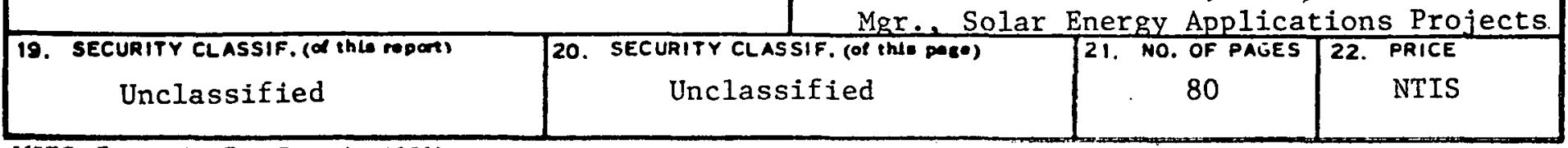


THIS PAGE

\section{WAS INTENTIONALLY LEFT BLANK}


TABLE OF CONTENTS

SECTION

TITLE

PAGE

1.

2.

2.1

2.2

3.

3.1

3.2

3.2 .1

3.2 .2

3.2 .3

3.2 .4

4.

5.

6.

7.

8.

APPENDIX A APPENDIX B APPENDIX $C$
FOREWORD .........................

SYSTEM DESCRIPTION ............... 2

TYPICAL SYSTEM OPERATION. ......... 7

SYSTEM OPERATING SEQUENCE . ....... 10

PERFORMANCE ASSESSMENT ................. 13

SYSTEM PERFORMANCE. .......... 14

SUBSYSTEM PERFORMANCE ........... 21

COLLECTOR ARRAY SUBSYSTEM. ....... 22

STORAGE SUBSYSTEM. .......... 37

HOT WATER SUBSYSTEM. ......... 40

SPACE HEATING SUBSYSTEM ........ 43

OPERATING ENERGY .............. 46

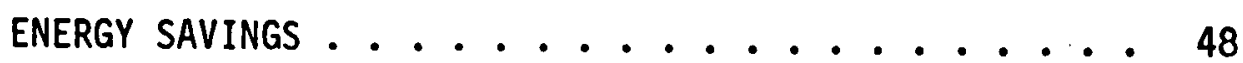

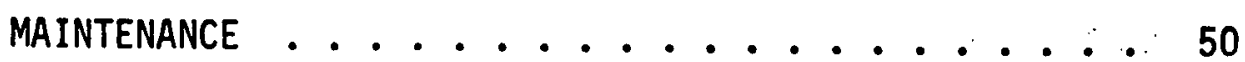

SUMMARY AND CONCLUSIONS. ........... 51

REFERENCES . . . ............. 54

DEFINITIONS OF PERFORMANCE FACTORS AND SOLAR TERMS .. A-1

SOLAR ENERGY SYSTEM PERFORMANCE EQUATIONS ...... B-1

LONG-TERM AVERAGE WEATHER CONDITIONS ........

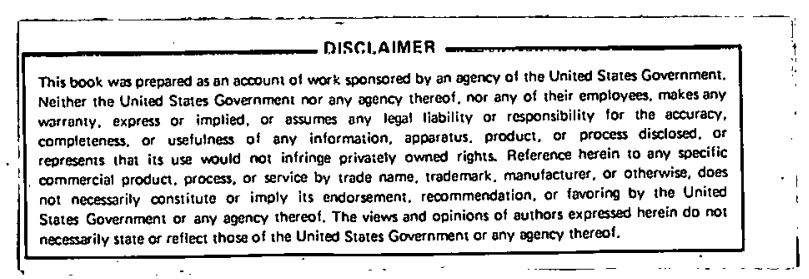




\section{LIST OF FIGURES AND TABLES}

2-1 Contemporary Newnan Solar Energy System Schematic .... . 3

2-2 Contemporary Newnan Pictorial .......... 4

2.1-1 Typical System Operating Parameters ......... 8

2.2-1 Typical System Operating Sequence.......... 11

3.1-1 Solar Energy System Evaluation Block Diagram. . . . . . 15

3.2.1-1 Collector Array Schematic . . . . . . . . . . . 23

3.2.1-2 Contemporary Newnan Collector Efficiency Curves ..... 30

3.2.1-3 Contemporary Newnan Operating Point Histograms . . . . . 35

TABLE

TITLE

PAGE

3.1-1 System Performance Summary. . . . . . . . . . . 17

3.2.1-1 . Collector Array Performance . . . . . . . . . . 24

3.2.1-2 Energy Gain Comparison ............. 32

3.2.2-1. Storage Subsystem Performance . ............ 39

3.2.3-1 Hot Water Subsystem Performance . . . . . . . . . 41

3.2.4-1 Heating Subsystem Performance . . . . . . . . . 45 45

$4-1$ Operating Energy ..................... 47

5-1 Energy Savings ..................... 49 


\section{FOREWORD}

The Solar Energy System. Performance Evaluation - Seasonal Report has been developed for the George C. Marshall Space Flight Center as a part of the Solar Heating and Cooling Development Program funded by the Department of Energy. The analysis contained in this document describes the technical performance of an Operational Test site (OTS) functioning throughout a specified period of time which is typically one season. The objective of the analysis is to report the long-term performance of the installed system and to make technical contributions to the definition of techniques and requirements for solar energy system design.

The contents of this document have been divided into the following topics of discussion:

- System Description

- Performance Assessment

- Operating Energy

- Energy Savings

- Maintenance

- Summary and Conclusions

Data used for the seasonal analyses of the Operational Test Site described in this document have been collected, processed and maintained under the OTS Development Program and have provided the major inputs used to perform the long-term technical assessment. This data is archived by MSFC for DOE.

The Seasonal Report document in conjunction with the Final Report for each Operational. Test Site in the Development Program culminates the technical activities which began with the site selection and instrumentation system design in April 1976. The Final Report emphasizes the economic analysis of solar systems performance and features the payback performance based on life cycle costs for the same solar system in various geographic regions. Other documents specifically related to this system are References [1], [2], and [3].*

*Numbers in brackets designate references found in Section 8 . 


\section{SYSTEM DESCRIPTION}

The Contemporary System 3 Solar Energy System is installed in a two story dwelling located in Newnan, Georgia approximately 40 miles southwest of Atlanta. The system was designed by Contemporary Systems Incorporated of Jaffrey, New Hampshire. The solar system is designed to provide space heating and domestic hot water ( $\mathrm{DHW}$ ) preheating for the residence.

Solar energy collection is performed by fourteen single glazed flat-plate collectors (Contemporary Systems Series $V$ Warm Air) with a total area of 392 square feet. The collectors are roof mounted on the dwelling and face due south with a tilt angle of 45 degrees. The heat transfer medium for the system is air and thermal storage is provided by a horizontal rock bin containing approximately 328 cubic feet of 1 to $11 / 2$ inch stones. Air movement for solar heat transfer in the system is accomplished by a central a ir handler with integral blower and damper controls for distribution of solar heated air to the heated space or to and from the rock storage bin. Auxiliary heating is provided by an electric heat pump supplemented by electric resistance heaters, when outdoor temperatures drop below $15^{\circ} \mathrm{F}$.

Hot water preheating is accomplished by an air-to-water heat exchanger, with separate fan coil unit, mounted near the collector outlet. Solar energy from this heat exchanger is supplied to an 80 gallon preheat tank which, in turn, supplies a conventional 40 gallon domestic hot water tank equipped with an electric heating element.

The system is shown schematically in Figure 2-1. The sensor designations are in accordance with NBSIR-76-1137 [5]. The measurement symbol prefixes: W, T, EP and I represent respectively: flow rate, temperature, electric power and insolation. Figure 2-2 is an pictorial view of the Contemporary Newnan installation.

The solar energy system has six modes of operation, which are described as follows: 


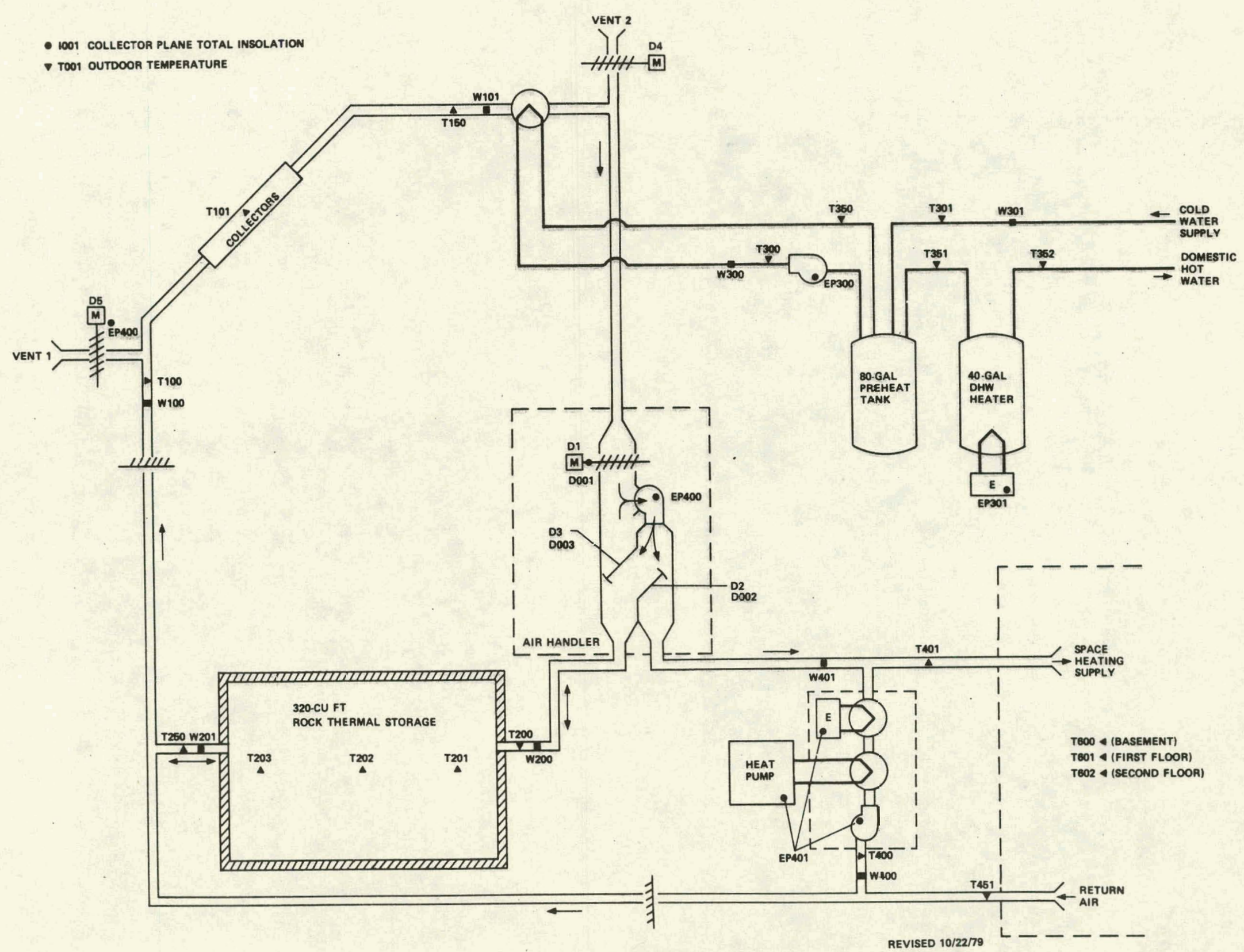

Figure 2-1 Contemporary System No.3, Newnan, GA., Solar Energy System Schematic 

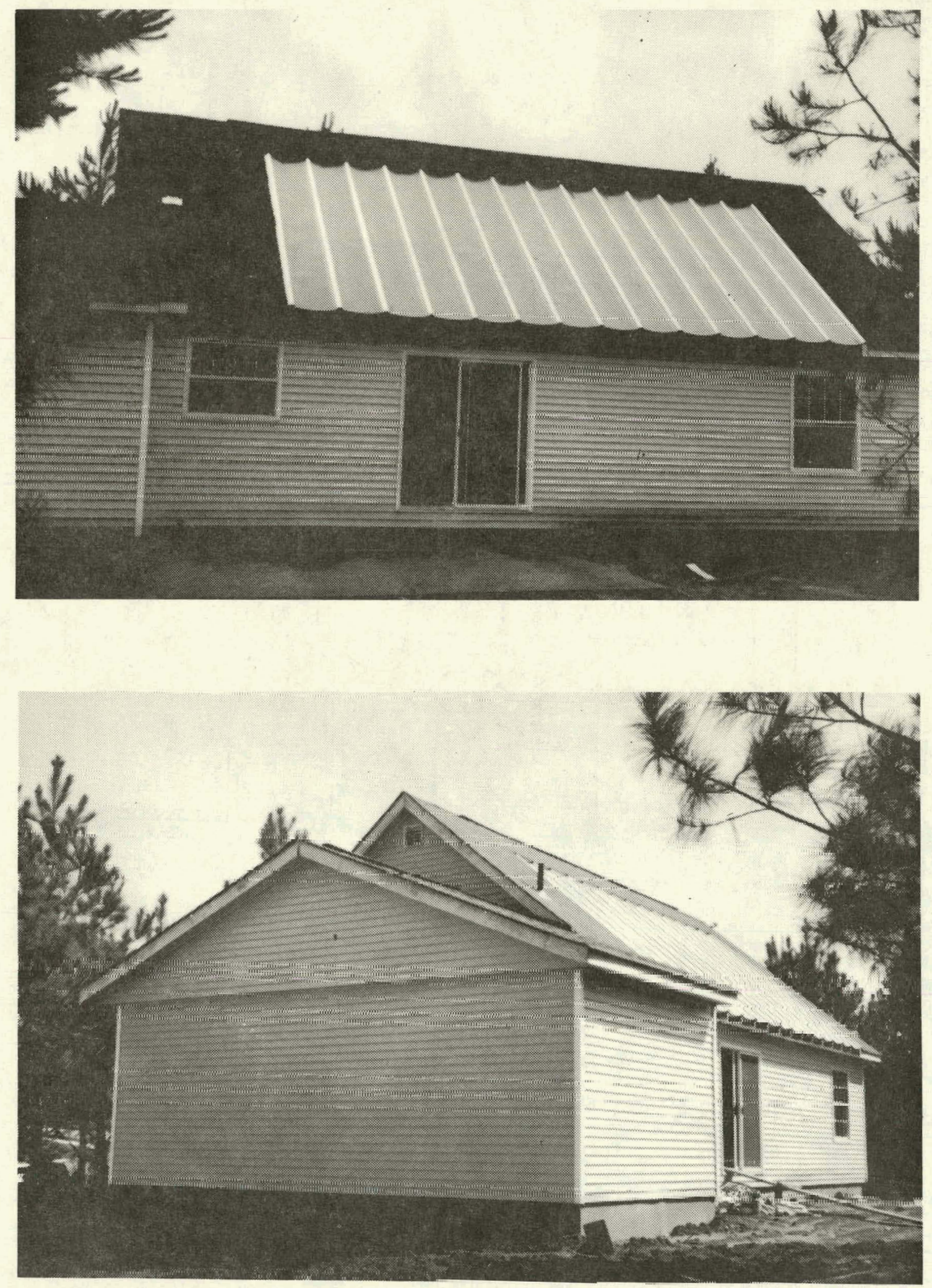

Figure 2-2 Contemporary Newnan Pictorfal 
Mode 1 -Collector-to-Space Heat Load: This mode is entered when the conditioned space thermostat calls for heat and the collector outlet temperature is sufficiently high, generally $100^{\circ} \mathrm{F}$ minimum. The main air handler blower will then be turned on and dampers positioned to allow delivery of solar heated air to the house. Operation in this mode is terminated when either the collector outlet temperature drops to $85^{\circ} \mathrm{F}$ or less, or the demand for space heating ceases.

Mode 2 - Collector-to-Storage: This mode is entered when there is no demand for heat to the conditioned space and the collector outlet temperature is yreater than that of the cold side of rock storage by a preset amount (nominally $15^{\circ} \mathrm{F}$ ). The air handler blower is then turned on and the control dampers positioned to cause solar heated air to be delivered to the rock bin.

Mode 3 - Heating From Storage: A demand for heat from the house thermostat, when there is insufficient heat from the collectors, causes the system to enter this mode. A "storage minimum" temperature of $90^{\circ} \mathrm{F}$ is preset in the system controller and the heating from storage mode is only entered when the hot side of storage exceeds this minimum setting. Operation in this mode is terminated when the hot side of storage falls below the "storage minimum" value, or the demand ceases.

Mode 4 - Auxiliary Heating: The auxiliary heating mode is entered when a heating demand exists and neither collector heating nor storage heating modes can occur. When operating in this mode, the air handler dampers are positioned to prevent reverse flow into the solar storage and collector loops and heat is supplied to the conditioned space from the heat pump and/or the electric resistance elements.

Mode 5 - Summer Venting: For warm weather or summer operation the system enters a thermosiphon venting mode through the use of damper controlled vents at the inlet side and outlet side of the collectors. Operation in this mode prevents excessive collector temperatures during periods of high insolation when no space heating demand exists. 
Mode 6 - Hot Water Preheating: Hot water preheating can be performed when the system is operating in either the collector-to-space heat load or collector-to-storage modes. Preheating can also be accomplished during summer operation provided that the collector outlet temperature is sufficiently above the preheat tank temperature and that venting control dampers are positioned (i.e., vents 1 and 2 opened) to permit thermosiphon air flow across the domestic hot water heat exchanger. 


\subsection{Typical System Operation}

Curves depicting typical system operation on a cold, bright day (February 17, 1980) are presented in Figure 2.1-1. Figure 2.1-1 (a) shows the insolation on the collector array and the period when the array was operating (shaded area). Also shown in Figure 2.1-1 (a) are the collector array temperature profiles. These are the inlet temperature $(\mathrm{T} 100)$, the outlet temperature (T150) and the absorber plate temperature (T101).

On this particular day, the collector array began operating at 1012 hours. At that time, the insolation level was $285 \mathrm{Btu} / \mathrm{ft}^{2}-\mathrm{Hr}$ and the absorber plate temperature ( $(101)$ was $143^{\circ} \mathrm{F}$. At the same time, the collector array inlet temperature $(\mathrm{T} 100)$ was $65^{\circ} \mathrm{F}$, and the outlet temperature was $120^{\circ} \mathrm{F}$, satisfying the control requirement that the outlet temperature be above $100^{\circ} \mathrm{F}$ for collector turn-on. Although collector operation is shown as continuous, from collector turn-on at 1012 hours until final turn-off at 1708 hours, there were six very short, (less than 10 minutes) widely separated turn-off periods during the day which account for the larger dips in the inlet and outlet temperatures.

The collector array operated normally throughout the day with the exception of the brief off periods cited above which, apparently, coincided with an operation mode change from Mode 1 (Collector-to-Space Heat Load) to Mode 2 (Collector-to-Storage). It is assumed that, in this mode transfer, the collector flow was momentarily interrupted by the switching of control dampers.

It will be noted that the absorber plate temperature (T101) and the collector outlet temperature (T150) generally tracked solar insolation and that these two temperatures $T 101$ and T150 tracked each other quite closely. The collector array inlet temperature ( $\mathrm{T} 100)$ showed a gradual rise throughout the operational period. This is expected because the system was operating in the collectorto-storage and hot water heating mode most of the day. As a result, T100 tended to track the temperature at the cold side of storage (T203).

The collector array continued to operate until 1708 hours at which time collector flow was terminated for the remainder of the day. At the time of 
(a)

INSOLATION

(BTU/FT2.HR)

COLLECTOR

TEMPERATURES

(OF)

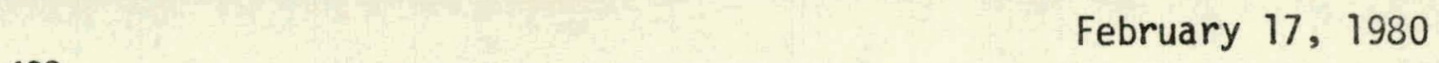

$\infty$

(b)

STORAGE

TEMPERATURE

(OF)
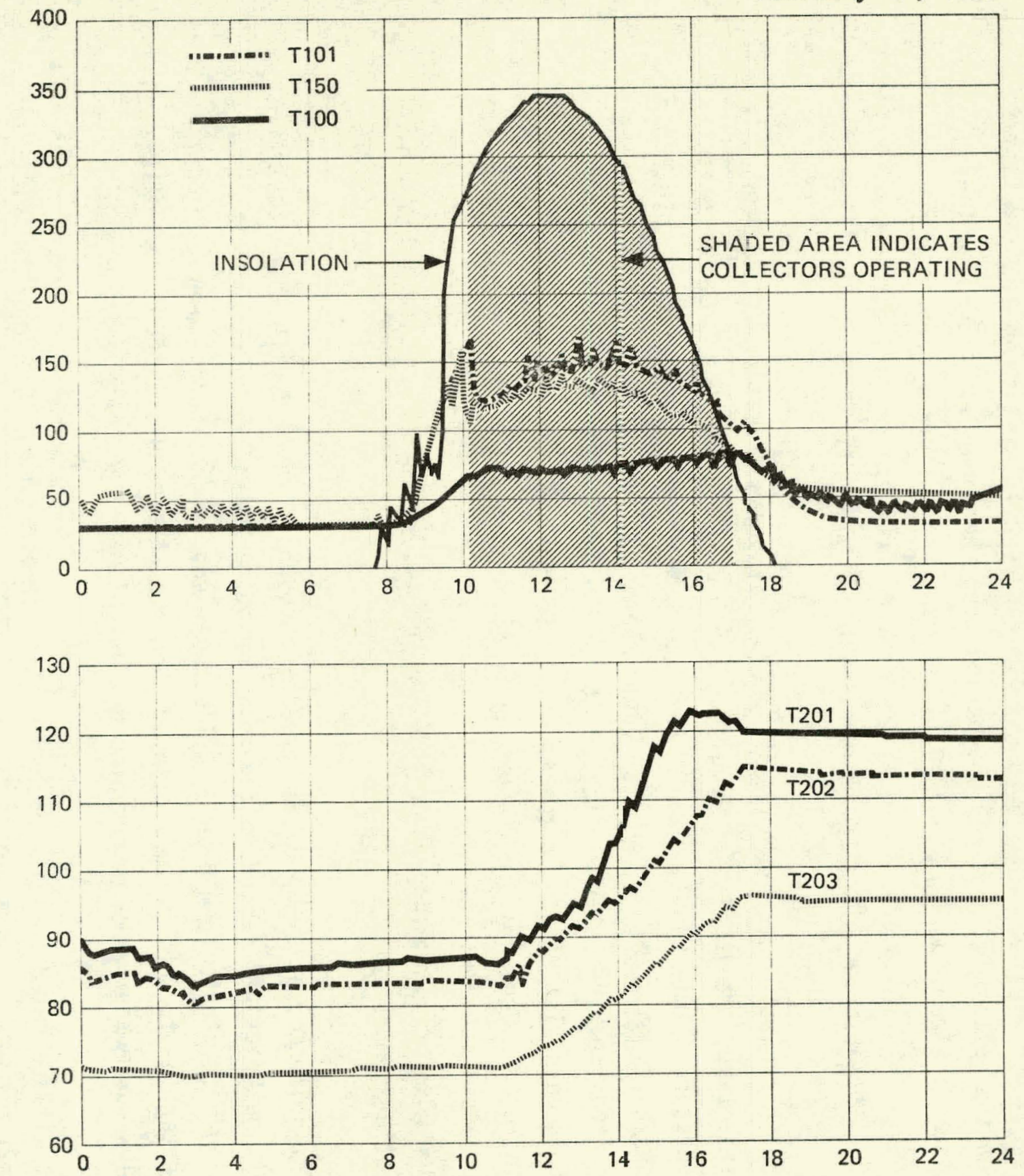

Figure 2.1-1 Typical System Operating Parameters - Contemporary Newnan 
collector turn-off the insolation level had dropped to $59 \mathrm{Btu} / \mathrm{Ft}^{2}-\mathrm{Hr}$ and absorber plate temperature (T101) had fallen to $99^{\circ} \mathrm{F}$. At turn-off, collector inlet temperature (T100) measured $82^{\circ} \mathrm{F}$ and collector outlet temperature (T150) was $81^{\circ} \mathrm{F}$. Thus, the system control operated approximately in accordance with design criteria which dictates that collector operation is terminated when the collector outlet temperature falls to $85^{\circ} \mathrm{F}$, or below. It should be noted that 7150 is a monitoring sensor. The control sensor, which is a separate and distinct sensor, may have detected a slightly different temperature value due to its location or type.

Figure 2.1-1 (b) presents a profile of the storage bin temperatures for the selected day. During the first three hours, the system was providing energy from storage for space heating. However, at 0305 hours the temperature at the hot side of storage (T201) dropped to approximately $84^{\circ} \mathrm{F}$ and heating from storage ceased until 0420 hours when it resumed for a very brief (less than 10 minute) period. At 0425, the temperature (T201) dropped to $85^{\circ} \mathrm{F}$ and heating from storage was terminated for the remainder of the day. This temperature is slightly below the control "storage minimum" temperature of $90^{\circ} \mathrm{F}$, however, it should be noted that T201 is not a control sensor. The actual control sensor probabiy sensed a different temperature due to its location in the rock bed. After 0420 hours the system remained in essentially a quiescent state until the collector array began operating and charging storage at approximately 1100 hours. During the charging period, from 1100 hours until 1700 hours, the temperature profile in the storage bin behaved as would be expected with all three storage temperatures increasing steadily. Once collector array operation, and hence storage charging, ceased, the system remained relatively stable for the remainder of the day. The system did not enter the storage to space heating mode during the evening hours. 


\subsection{System Operating Sequence}

Figure 2.2-1 presents bar charts showing typical system operating sequences for February 17, 1980. This data correlates with the curves presented in Figure 2.1-1 and provides some additional insight into those curves. This particular day was chosen because almost all possible modes of system operation were exercised at some time during the day.

February 17 was an appropriate day to evaluate the performance of the space heating subsystem in view of the relatively cold average ambient temperature for the day $\left(30^{\circ} \mathrm{F}\right)$ and a sizable heating load $(245,000 \mathrm{Btu})$. On that date, solar energy satisfied 34 percent of the space heating load and 29 percent of the hot water load.

As shown in Figure 2.2-1, space heating was provided from storage in a cyclic fashion from midnight until about 0420 hours. During this period, the heat from storage was supplemented by cycling of the heat pump until after 0420 hours when the heat pump ran continuously until approximately 1000 hours when collector turn-on occurred. From about 1020 hours until 1100 hours the system provided heat directly from the collectors to the heated space. From 1100 hours until collector turn-off, just after 1700 hours, the system cycled between direct heating from the collectors and charging storage. Over this period, the majority of the system operation was in the storage charging mode. This is reflected in the significant storage temperature increase during the operational period. By the end of the collector operating period, at 1708 hours, the temperature (T201) at the hot side of storage had reached $120^{\circ} \mathrm{F}$. An apparent misadjustment in the system controls caused all space heating after collector turn-off to be provided by the auxiliary source (heat pump) despite the fact that storage temperatures seemed adequate to provide significant energy during the evening hours.

Figure 2.2-1 also shows that preheating of domestic hot water was carried out continuously during the operational period of the collectors. Domestic hot water usage on the day selected totaled 124 gallons. This is a little higher than the monthly average for February of 105 gallons. Time phasing of the hot water demand is indicated in Figure 2.1-1. 
In general, the system operated in accordance with design criteria except that available energy from storage was not utilized in the evening hours. This resulted in the unnecessary expenditure of auxiliary energy for space heating. 


\section{PERFORMANCE ASSESSMENT}

The performance of the Contemporary Newnan Solar Energy System has been evaluated for the June, 1979, through April, 1980, time period from two perspectives. The first was the overall system view in which the performance values of system solar fraction and net energy savings were evaluated against the prevailing and long-term average climatic conditions and system loads. The second view presents a more in depth look at the performance of the individual subsystems. Details relating to the performance of the system are presented first in Section 3.1 followed by the subsystem assessment in Section 3.2 . 


\subsection{System Performance}

This Seasonal Report provides a system performance evaluation summary of the operation of the Contemporary Newnan Solar Energy System located in Newnan, Georgia. This analysis was conducted by evaluation of measured system performance against the expected performance with long-term average climatic conditions. The performance of the system is evaluated by calculating a set of primary performance factors which are based on those proposed in the intergovernmental agency report, "Thermal Data Requirements and Performance Evaluation Procedures for the National Solar Heating and Cooling Demonstration Program" [5]. The performance of the major subsystems is also evaluated in subsequent section of this report.

The measurement data were collected for the period June, 1979, through Apri1, 1980. System performance data were provided through an IBM developed Central Data Processing System (CDPS) [4] consisting of a remote Site Data Acquisition System (SDAS), telephone data transmission lines and couplers, an IBM System 7 computer for data management, and an IBM System 370/145 computer for data processing. The CDPS supports the collection and analys is of solar data acquired from instrumented systems located throughout the country. These data are processed daily and summarized into monthly performance formats which form a common basis for comparative system evaluation. These monthly summaries are the basis of the evaluation and data contained in this report.

The solar energy system performance summarized in this section can be viewed as the dependent response of the system to certain primary inputs. This-relationship is illustrated in Figure 3.1-1. The primary inputs are the incident solar energy, the outdoor ambient temperature and the system load. The dependent responses of the system are the system solar fraction and the total energy savings. Both the input and output definitions are as follows: 


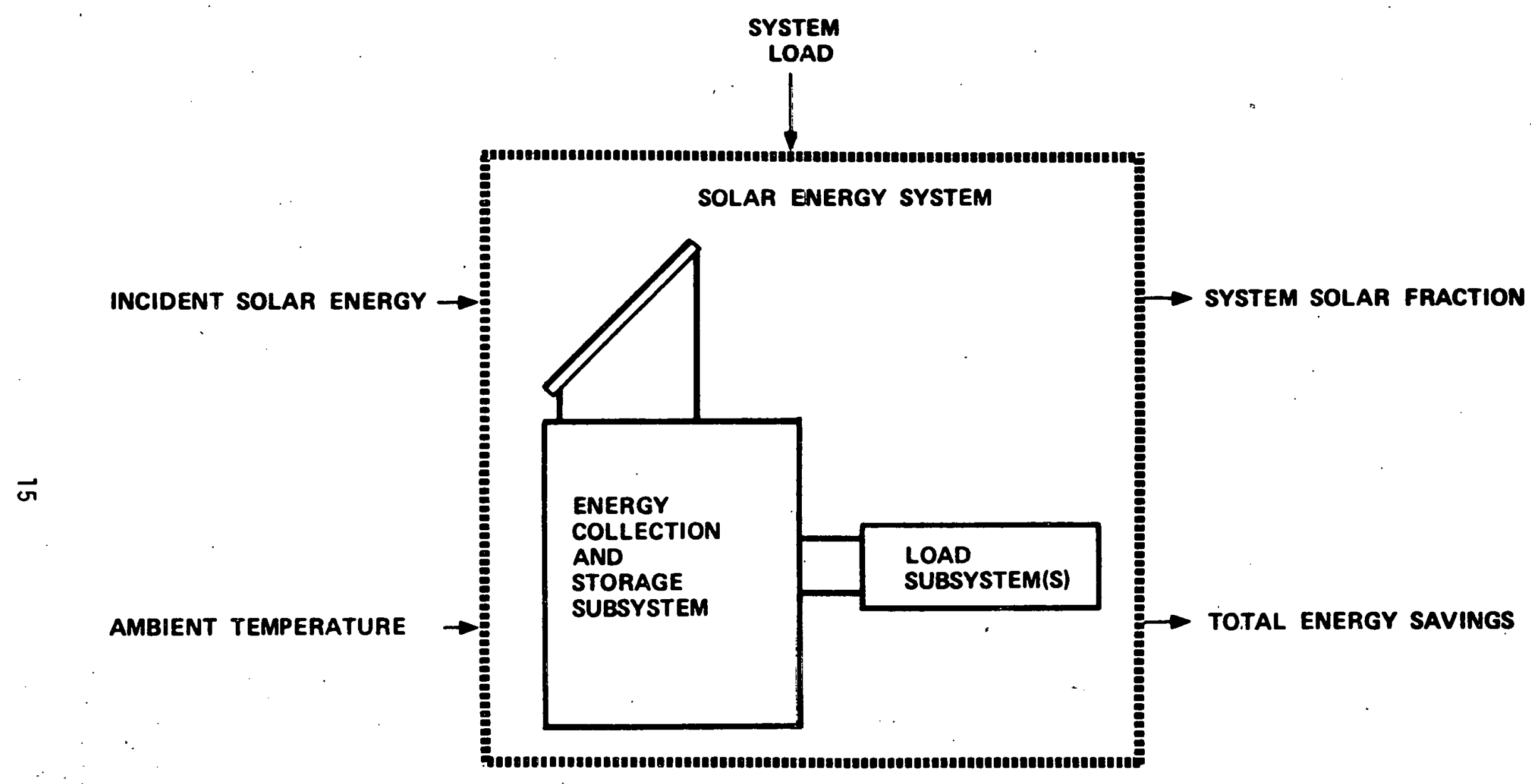

Figure 3.1-1 Solar Energy System Evaluation Block Diagram 


\section{Inputs}

- Incident solar energy - The total solar energy incident on the collector array and available for collection.

- Ambient temperature - The temperature of the external environment which affects both the energy that can be collected and the energy demand.

- System load - The loads that the system is designed to meet, which are affected by the life style of the user (space heating/cooling, domestic hot water, ctc., as applicable).

\section{Outputs}

- System solar fraction - The ratio of solar energy applied to the system loads to total energy (solar plus auxiliary energy) required by the loads.

- Total energy savings - The quantity of auxiliary energy (electrical or fossil) displaced by solar energy.

The monthly values of the inputs and outputs for the total operational period are shown in Table 3.1-1, the System Performance Summary. Comparative long-term average values of daily. incident solar energy, and outdoor ambient temperature are given for reference purpose. The long-term data are taken from Reference 1 of Appendix $C$. Generaliy the solar energy system is designed to supply an amount of energy that results in a desired value of system solar fraction while operating under climatic conditions that are defined by the long-term average value of daily incident solar energy and 
TABLE $3.1-1$

SYSTEM PERFORMANCE SUMMARY

\section{CONTEMPORARY NEWNAN}

\begin{tabular}{|c|c|c|c|c|c|c|c|c|}
\hline \multirow[b]{2}{*}{ Month } & \multicolumn{2}{|c|}{$\begin{array}{l}\text { Daily Incident Solar } \\
\text { Energy per Unit Area } \\
\text { o } 45^{\circ} \text { Tilt (Btu/Ft2 Day) }\end{array}$} & \multicolumn{2}{|c|}{$\begin{array}{c}\text { Ambient } \\
\text { Temperature } \\
{ }^{\circ} \mathrm{F}\end{array}$} & \multirow{2}{*}{$\begin{array}{c}\begin{array}{c}\text { System } \\
\text { Load- } \\
\text { Measured }\end{array} \\
\text { (Million Btu) }\end{array}$} & \multicolumn{2}{|c|}{$\begin{array}{l}\text { Solar } \\
\text { Fraction } \\
\text { (Percent) }\end{array}$} & \multirow{2}{*}{$\begin{array}{l}\begin{array}{l}\text { Total } \\
\text { Energy } \\
\text { Savings }\end{array} \\
\text { (Million Btu) }\end{array}$} \\
\hline & Measured & $\begin{array}{l}\text { Long-Term } \\
\text { Average. }\end{array}$ & Measured & $\begin{array}{l}\text { Long-Term } \\
\text { Average }\end{array}$ & & - Mea sured & Expected & \\
\hline Jun 79 & 1448 & 1494 & 74 & 76 & 0.056 & 0 & 0 & -0.211 \\
\hline Jut 79 & 1151 & 1454 & 77 & 79 & 0.247 & 17 & 40 & -0.133 \\
\hline Aug 79 & 1585 & 1528 & 77 & 78 & 0.112 & 0 & 86 & -0.025 \\
\hline Sep 79 & 1001 & 1508 & 71 & 73 & 0.244 & 4 & 57 & -0.117 \\
\hline Oct 79 & 1587 & 1579 & 59 & 63 & 1.479 & 92 & 83 & 0.439 \\
\hline Nov 79 & 1259 & 1368 & 50 & 52 & 2.381 & 68 & 55 & 0.774 \\
\hline Dec 79 & 1108 & 1107 & 43 & 45 & 6.326 & 44 & 30 & 1.241 \\
\hline Jan 80 & 714 & 1112 & 43 & 44 & 7.112 & 19 & 7 & 0.617 \\
\hline Feb 80 & 1380 & 1311 & 40 & 46 & 7.272 & 36 & 31 & 1.188 \\
\hline Mar 80 & 1222 & 1488 & 50 & 52 & 4.377 & 50 & 37 & 1.026 \\
\hline Apr 80 & 1459 & 1602 & 59 & 62 & 2.140 & 66 & 54 & 0.674 \\
\hline Total & 13914 & 15551 & - & - & 31.746 . & - & - & 5.473 \\
\hline Average & 1265 & 1414 & 58 & 61 & 2.88 & 42 & 32 & 0.50 \\
\hline
\end{tabular}

* Averages are weighted values. 
outdoor ambient temperature. If the actual climatic conditions are close to the long term average values, there is little adverse impact on the system's ability to meet design goals. This is an important factor in evaluating system performance and is the reason the longterm average values are given. The data reported in the following paragraphs are taken from Table 3.1-1.

At the Contemporary Newnan site for the eleven month report period, the long-term average daily incident solar energy in the plane of the collector was $1414 \mathrm{Btu} / \mathrm{ft}^{2}$. The average dafly measured value was 1265 $\mathrm{Btu} / \mathrm{ft}^{2}$ which is about 11 percent 'below the long-term value. On a monthily basis, January of 1980 was the worst month with an average daily measured value of incident solar energy 36 percent below the long-term average daily value. February, 1980, was the best month with an average daily measured value five percent above the long-term average daily value. On a long-term basis the measured value of incident solar energy was sufficiently below the long-term value to have a slightly detrimental effect on the performance of the solar energy system.

The outdoor ambient temperature influences the operation of the solar energy system in two important ways. First the operating point of the collectors and consequently the collector efficiency or energy gain is determined by the difference in the outdoor ambient temperature and the collector inlet temperature. This will be discussed in greater detail in Section 3.2.1. Secondly the load is influenced by the outdoor ambient temperature. The measured average daily ambient temperature was $58^{\circ} \mathrm{F}$ for the Contemporary Newnan site which is $3^{\circ} \mathrm{F}$ below the long-term value of $61^{\circ} \mathrm{F}$. On a monthly basis, February of 1980 was the worst month, temperaturewise, when the measured temperature was $6^{\circ} \mathrm{F}$ below the long-term daily average. This lower than normal temperature had a slightly adverse impact on system performance, despite the fact that February was the best of the report months in terms of incident solar energy. 
The effect of system load and ambient temperature on the performance of the Contemporary Newnan Solar Energy System can be seen by reference to Table 3.1-1. The maximum solar fraction of 92 percent was achieved in October, 1979, when system load was low, incident solar energy was slightly above the long-term average and ambient temperature was only $4^{\circ} \mathrm{F}$ below the long-term value. The lowest solar fraction of 19 percent was measured in January, 1980, when system load was near its peak value and incident solar energy was 36 percent below the long-term value.

The low (and zero) solar fractions obtained in the June, 1979 through September, 1979 time period are not considered a true measure of system performance because the heating load was zero or negligible and there was essentially no hot water load except in July when water from the DHW subsystem was used in a non-typical fashion for cleaning purposes.

Also presented in Table 3.1-1 are the measured and expected values of system solar fraction where system solar fraction is the ratio of solar energy applied to the loads. The expected values have been derived from a modified f-Chart analysis which uses measured weather and subsystem loads as inputs ( $f$-Chart is the designation of a procedure that was developed by the Solar Energy Laboratory, University of Wisconsin, Madison, for modeling and designing solar energy system [9]). The model used in the analysis is based on manufacturers' data and other known system parameters. The bases for the model are empirical correlations developed for liquid and air solar energy systems that are presented in graphical and equation form and referred to as the $f$-Chart where ' $f$ ' is a designator for the system solar fraction. The output of the f-chart procedure is the expected system solar fraction. The measured value of system solar fraction was computed from measurements obtained through the instrumentation system of the energy transfers that took place within the solar energy system. These represent the actual performance of the system installed at the site. 
The total energy saving is an important performance parameter for the solar energy system because the fundamental purpose of the system is to replace expensive conventional energy sources with less expensive solar energy. In practical consideration, the system must save enough energy to cover both the cost of its own operation and to repay the initial investment for the system. In terms of the technical analysis presented in this report the net total energy savings should be significant positive figure. The total net energy savings for the Contemporary Newnan Solar Energy System was 5.47 million Btu or 1602 kWh. These savings are based only on measured inputs of solar energy to the load subsystems. Consideration of the considerable solar energy system losses in the form of storage and transport losses which are introduced into the heated space and which, therefore, reduce the overall heating load, results in significantly greater savings for the system. These losses and the resultant savings are discussed in detail in sections that follow. 


\subsection{Subsystem Performance}

The Contemporary Newnan Solar Energy Installation may be divided into four subsystems:

1. Collector array

2. Storage

3. Hot water

4. Space Heating

Each subsystem has becn evaluated by the techniques defined in Section 3 and is numerically analyzed each month for the monthly performance assessments. This section presents the results of integrating the monthly data available on the four subsystems for the period June, 1979, through Apri1, 1980. 


\subsubsection{Collector Array Subsystem}

The Contemporary Newnan collector array consists of 14 Contemporary Systems Series $V$ warm air flat-plate air collectors connected in parallel. These collectors are a one-pass air heating type with a double glazing making up an array with a gross area of 392 square feet. Interconnection and flow details are shown in Figure 3.2.1-1 (a) and (b). The collector subsystem analysis and data are given in the following paragraphs.

Collector array performance is described by the collector array efficiency. This is the ratio of collected solar energy to incident solar energy, a value always less than unity because of collector losses. The incident solar energy may be viewed from two perspectives. 'The' first assumes that all available solar energy incident on the collectors must be used in determining collector array efficiency. The efficiency is then expressed by the equation:

$$
n_{c}=Q_{s} / Q_{i}
$$

where

$$
\begin{aligned}
& n_{c}=\text { Collector array efficiency } \\
& Q_{s}=\text { Collected solar energy } \\
& Q_{i}=\text { Incident snlar energy }
\end{aligned}
$$

The efficiency determined in this manner includes the operation of the control system. For example, solar energy can be available at the collector, but the collector absorber plate temperature may be below the minimum control temperature set point for collector loop operation, thus the energy is not collected. The monthly efficiency by this method is listed in the column entitled "Collector Array Efficiency" in Table 3.2.1-1. 


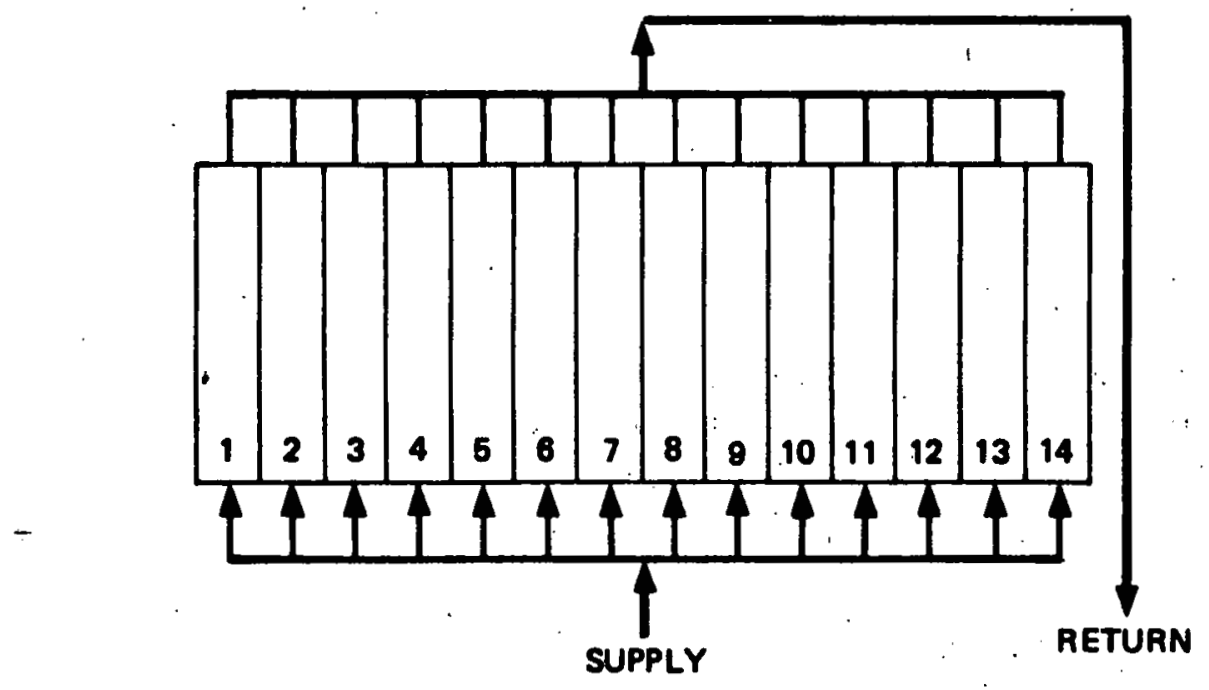

(a) Colloctor Array Arrongement

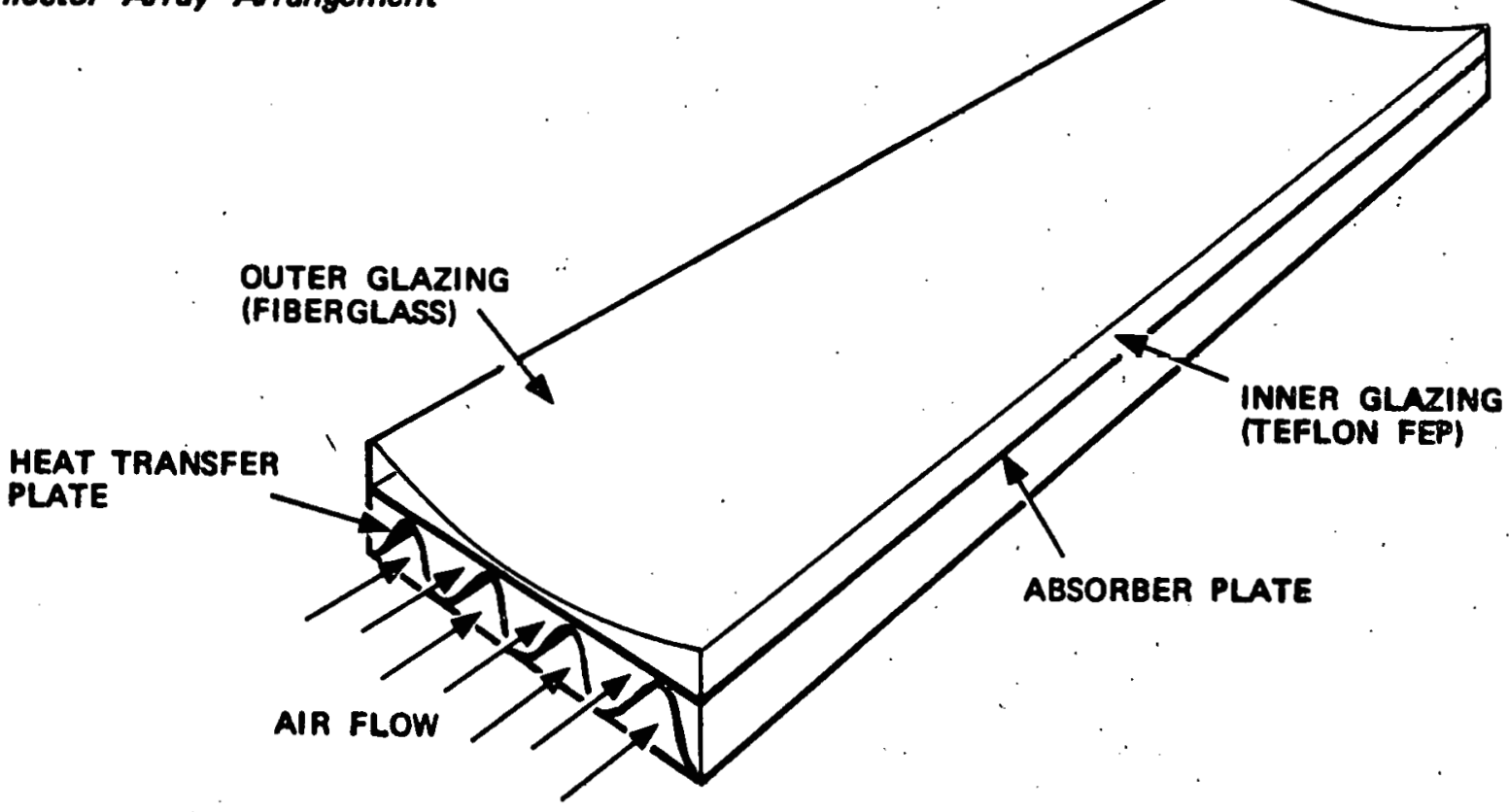

(b) Colloctor Panol Air Flow Path

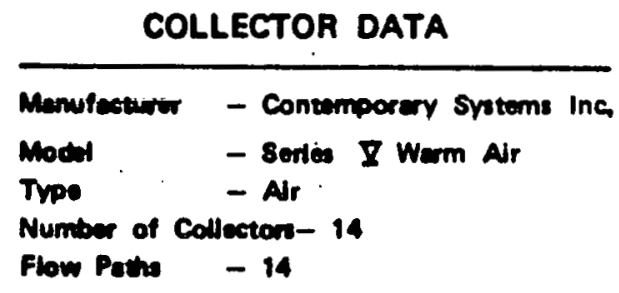

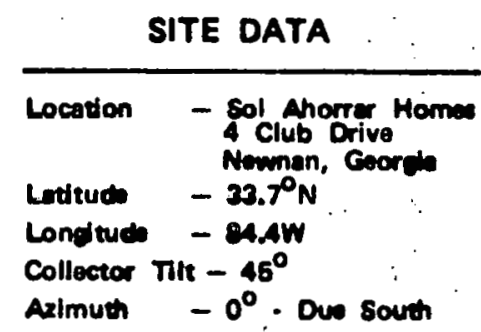

Figure 3.2.1-1 Collector Array Schematic 
TABLE 3.2.1-1

COLLECTOR ARRAY PERFORMANCE

\begin{tabular}{|c|c|c|c|c|c|}
\hline Month & $\begin{array}{l}\text { Incident } \\
\text { Solar Energy } \\
\text { (Million Btu) }\end{array}$ & $\begin{array}{c}\text { Collected } \\
\text { Solar Energy } \\
\text { (Million Btu) }\end{array}$ & $\begin{array}{l}\text { Collecter } \\
\text { Array } \\
\text { Efficiercy }\end{array}$ & $\begin{array}{c}\text { Operational } \\
\text { Incident Energy } \\
\text { (Million Btu) }\end{array}$ & $\begin{array}{c}\text { Operational } \\
\text { Collector Arra } \\
\text { Efficiency }\end{array}$ \\
\hline Jun 79 & 17.033 & 2.237 & 0.13 & 9.465 & 0.24 \\
\hline Jul 79 & 13.986 & 1.697 & 0.12 & 6.481 & 0.26 \\
\hline Aug 79 & 19.262 & 0.006 & 0.00 & 0.272 & 0.02 \\
\hline Sep 79 & 11.775 & 1.366 & 0.12 & 4.172 & 0.33 \\
\hline Oct 79 & 19.287 & 4.266 & 0.22 & 15.042 & 0.28 \\
\hline Nov 79 & 14.809 & 3.170 & 0.21 & 11.854 & 0.27 \\
\hline Dec 79 & 13.465 & 4.151 & 0.31 & 10.981 & 0.38 \\
\hline Jan 80 & 8.671 & 2.384 & 0.27 & 6.260 & 0.38 \\
\hline Feb 80 & 15.683 & 4.407 & 0.28 & 12.485 & 0.35 \\
\hline Mar. 80 & 14.855 & 3.927 & 0.26 & 11.692 & 0.34 \\
\hline Apr 80 & 17.157 & 3.152 & 0.18 & 12.214 & 0.26 \\
\hline Total & 165.983 & $3 c .763$ & -- & 100.918 & -- \\
\hline Average & 15.09 & 2.80 & 0.19 & 9.17 & 0.30 \\
\hline
\end{tabular}


The second viewpoint assumes that only the solar energy incident on the collector when the collector loop is operational be used in determining the collector array efficiency. The value of the operational incident solar energy used is multiplied by the ratio of the gross collector area to the gross collector array area to compensate for the difference between the two areas caused by installation spacing. The efficiency is then expressed by the equation:

$$
n_{c o}=Q_{s} /\left(Q_{o i} \times A_{p} / A_{a}\right)
$$

$$
\text { where } \begin{aligned}
n_{c 0}= & \text { Operational collector array efficiency } \\
Q_{s}= & \text { Collected solar energy } \\
Q_{0 i}= & \text { Operational incident solar energy } \\
A_{p}= & \begin{array}{l}
\text { Gross collector area (the product of } \\
\text { the number of collectors and the } \\
\text { envelope area of one collector) }
\end{array} \\
A_{a}= & \begin{array}{l}
\text { Gross collector array area (total area } \\
\text { including all mounting and connecting } \\
\text { hardware and spacing of units) }
\end{array}
\end{aligned}
$$

The monthly efficiency computed by this method is listed in the column entitled "Operational Collector Array Efficiency" in Table 3.2.1-1.

In the ASHRAE Standard 93-77 [6] a collector efficiency is defined in the same terminology as the operational collector array efficiency. However, the ASHRAE efficiency is determined from instantaneous evaluation under tightly controlled, steady state test conditions, while the operational collector array efficiency is determined from actual dynamic conditions of daily solar energy system operation in the field.

The ASHRAE Standard 93-77 definitions and methods often are adopted by collector manufacturers and independent test laboratories in evaluating collectors. The collector evaluation performed for this report using the 
field data indicates that there was a significant difference between laboratory calibrated single panel collector data and the collector data determined from long-term field measurements. This may not always be the case, but there are two primary reasons for differences in the laboratory and field data:

- Test conditions are not the same as conditions in the field, nor do they represent the wide dynamic range of field operation (i.e. inlet and outlet temperature, flow rates and flow distribution of the heat transfer fluid, insolation levels, aspect angle, wind conditions, etc.)

- Collector tests are not generally conducted with units that have undergone the effects of aging (i.e. changes in the characteristics of the glazing material, collection of dust, soot, pollen or other foreign material on the glazing, deterioration of the absorber plate surface treatment, etc:)

Consequently field data collected over an extended period will generally provide an improved source of collector performance characteristics for use in long-term system performance definition.

The long-term data base for Contemporary Newnan used for detailed collector analysis includes all but two of the months in the June, 1979, through April, 1980, report period. August, 1979, was omitted from the data base because the hot water load was negligible (28 gallons for the month) and the small heating load was supported by the auxiliary system. As a result, the solar energy collected was less than one percent of the incident solar energy. Data for the month of October, 1979, was lost due to a parity error on the detail measurement tape and that month is, therefore, omitted from the long-term data base.

The operation collector array efficiency data given in Table 3.2.1-1 are monthly averages based on instantaneous efficiency computations over the total performance period using all available data. For detailed collector analysis it was desirable to use a limited subset of the available data that characterized collector operation under "steady state" conditions. This subset was defined by applying the following restrictions: 
(1) The measurement period was restricted to collector operation when the sun angle was within 30 degrees of the collector normal.

(2) Only measurements associated with positive energy gain from the collectors were used, i.e., outlet temperatures must have exceeded inlet temperatures.

(3) The sets of measured parameters were restricted to those where the rate of change of all parameters of interest during two regular data system intervals* was limited to a maximum of 5 percent.

Instantaneous efficiencies $\left(n_{j}\right)$ computed from the "steady state" operation measurements of incident solar energy and collected solar

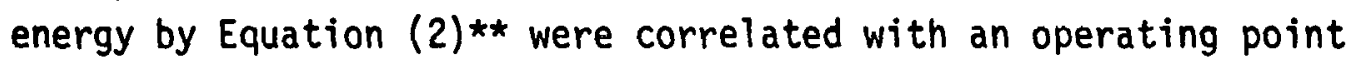
determined by the equation:

$$
x_{j}=\frac{T_{i}-T_{a}}{I}
$$

where $\quad x_{j}=\begin{aligned} & \text { Collector operating point at the } j^{\text {th }} \\ & \text { instant }\end{aligned}$

$$
\begin{aligned}
& T_{\mathbf{i}}=\text { Collector inlet fluid temperature } \\
& T_{a}=\text { Outdoor ambient temperature } \\
& I=\text { Rate of incident solar radiation }
\end{aligned}
$$

The data points $\left(n_{j}, x_{j}\right)$ were then plotted on a graph of efficiency versus operating point and a first order curve described by the slopeintercept formula was fitted to the data through linear regression techniques. The form of this fitted efficiency curve is:

\footnotetext{
*The data system interval was $5-1 / 3$ minutes in duration. Values of

all measured parameters were continuously sampled at this rate throughout the performance period.

**The ratio $A_{p} / A_{a}$ was assumed to be unity for this analysis.
} 


$$
n_{j}=b-m x_{j}
$$

$$
\text { where } \begin{aligned}
n_{j} & =\begin{array}{l}
\text { Collector efficiency corresponding to the } \\
j \text { th instant }
\end{array} \\
b & =\text { Intercept on the efficiency axis } \\
(-) m & =\text { Slope } \\
x_{j} & =\begin{array}{l}
\text { Collector operating point at } j t h \\
\text { instant }
\end{array}
\end{aligned}
$$

The relationship between the empirically determined efficiency curve and the analytically developed curve will be established in subsequent paragraphs.

The analytically developed collector efficiency curve is based on the Hottell-Whillier-Bliss equation:

$$
n=F_{R}(\tau \alpha)-F_{R} U_{L}\left(\frac{T_{i}-T_{a}}{I}\right)
$$

$$
\text { where } \begin{aligned}
n & =\text { Collector efficiency } \\
F_{R} & =\text { Collector heat removal factor } \\
\tau & =\text { Transmissivity of ccllector glazing } \\
\alpha & =\text { Absorptance of collector plate } \\
U_{L} & =\text { Overall collector energy loss coefficient } \\
T_{i} & =\text { Coilector inlet fluid temperature } \\
T_{\mathbf{a}} & =\text { Outdoor ambient temperature } \\
I & =\text { Rate of incident solar radiation }
\end{aligned}
$$


The correspondence between equations (4) and (5) can be readily seen. Therefore by determining the slope-intercept efficiency equation from measurement data, the collector performance parameters corresponding to the laboratory single panel data can be derived according to the following set of relationships:

$$
\begin{aligned}
& b=F_{R}(\tau \alpha) \\
& \text { and } \\
& m=F_{R} U_{L}
\end{aligned}
$$

where the terms are as previously defined

The discussion of the collector array efficiency curves in subsequent paragraphs is based upon the relationships expressed by Equation (6).

In deriving the collector array efficiency curves by the linear regression technique, measurement data over the entire performance period yields higher confidence in the results than similar analysis over shorter periods. Over the longer periods the collector array is forced to operate over a wider dynamic range. This eliminates the tendency shown by some types of solar energy systems to cluster efficiency values over a narrow range of operating points. The clustering effect tends to make the linear regression technique approach constructing a line through a single data point. The use of data from the entire performance period results in a collector array efficiency curve that is more accurate in long-term solar system performance prediction. The long-term curve and the curve derived from the laboratory single panel data are shown in Figure 3.2.1-2.

The long-term first order curve presented in Figure 3.2.1-2 indicates that the collector as a whole did not perform as well as the laboratory test unit. Over the reporting period the average operating point of the collector array was in the 0.10 to 0.20 range and, within this range, the collector efficiency was 6 percent to 10 percent below the value obtained from laboratory single panel test data. This is probably due to the differences between laboratory and field conditions, as cited earlier (flow rates, aspect angle and 


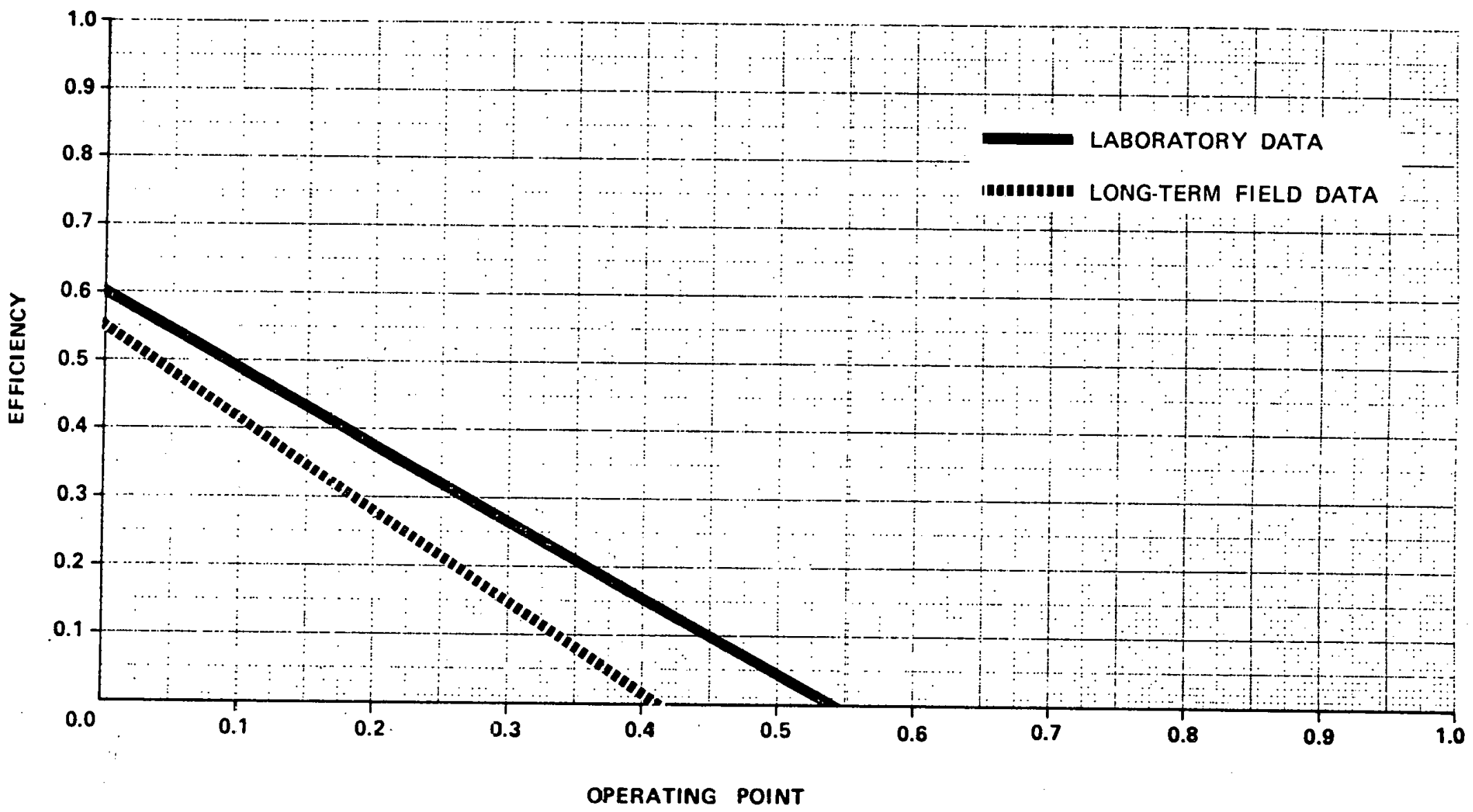

Figure 3.2.1-2 Contemporary Newnan Collector Efficlency Curves 
wind conditions) and to leakage effects associated with the manifolds and duct work for the complete array as opposed to those required for a single pane1. These effects also resulted in a slightly more negative slope in the long-term first order curve compared to the single panel test curve.

Table 3.2.1-2 presents data comparing the monthly measured values of solar energy collected with the predicted performance determined from the long-term regression curve and the laboratory single panel efficiency curve. The predictions were derived by the following procedure:

1. The instantaneous operating points were computed using Equation (3).

2. The instantaneous efficiency was computed using Equation (4) with the operating point computed in Step 1 above for:

a. The long-term linear regression curve for collector array efficiency

b. The laboratory single panel collector efficiency curve

3. The efficiencies computed in Steps $2 a$ and $2 b$ above were multiplied by the measured solar energy available when the collectors were operational to give two predicted values of solar energy collected.

The error data in Table 3.2.1-2 were computed from the differences between the measured and predicted values of solar energy collected according to the equation: 
TABLE 3.2.1-2

ENERGY GAIN COMPARISON

(ANNUAL)

SITE: CONTEMPOFARY NEWNAN

NEWNAN, GEORGIA

\begin{tabular}{|c|c|c|c|}
\hline & $\begin{array}{l}\text { Callected } \\
\text { Sclar Enercy } \\
\text { Month }\end{array}$ & \multicolumn{2}{|c|}{ Error } \\
\hline Jun 79ilian Btu) & $\begin{array}{c}\text { Field Derivec } \\
\text { Long-Term }\end{array}$ & $\begin{array}{c}\text { Laboratory } \\
\text { Single Panel }\end{array}$ \\
\hline Ju7 79 & 2.299 & 0.000 & -0.274 \\
Sep 79 & 1.778 & 0.000 & -0.279 \\
Nov 79 & 1.343 & 0.284 & -0.143 \\
Dec 79 & 3.194 & 0.033 & -.0 .241 \\
Jan 80 & 4.236 & 0.096 & -0.095 \\
Feb 80 & 2.451 & 0.079 & -0.101 \\
Mar 80 & 4.506 & 0.064 & -0.136 \\
Apr 80 & 3.930 & 0.026 & -0.173 \\
\hline Average & 3.027 & -0.108 & -0.311 \\
\hline
\end{tabular}




$$
\text { Error }=(A-P) / P
$$

where $A=$ Measured solar energy collected

$P=$ Predicted solar energy collected

The computed error is then an indication of how well the particular prediction curve fitted the reality of dynamic operating conditions in the field.

The values of "Collected Solar Energy" given in Table 3.2.1-2 are not necessarily identical with the values of "Collected Solar Energy" given in Table 3.2.1-1. Any variations are due to the differences in data processing between the software programs used to generate the monthly performance report data and the component level collector analysis program. These data are shown in Table 3.2.1-2 only because they form the references from which the error data given in the table are computed.

The data from Table 3.2.1-2 illustrates that for the Coritemporary Newnan site the average error computed from the difference between the measured solar energy collected and the predicted solar energy collected based on the field derived long-term collector array efficiency curve was 5.3 percent. For the curve derived from the laboratory single panel data, the error was -19.5 percent. Thus the long-term collector array efficiency curve gives significantly better results than the laboratory single panel curve in describing collector performance in this system.

A histogram of collector array operating points illustrates the distribution of instantaneous values as determined by Equation (3) for the entire month. The histogram was constructed by computing the instantaneous operating point value from site instrumentation measurements at the regular data system intervals throughout the month, and counting the number of values within contiguous intervals of width 0.01 from zero 
to unity. The operating point histogram shows the dynamic range of collector operation during the month from which the midpoint can be ascertained. The average collector array efficiency for the month can be derived by projecting the midpoint value to the appropriate efficiency curve and reading the corresponding value of efficiency.

Another characteristic of the operating point histogram is the shifting of the distribution along the operating point axis. This can be explained in terms of the characteristics of the system, the climatic factors of the site, i.e., incident solar energy and ambient temperature and the method of system operation. Figure 3.2.1-3 shows two histograms that illustrate a typical winter month (February) and a typical. summer month (June) operation. The approximate average operating point for February is at 0.12 and for June at 0.19. In terms of Equation (3) it can be seen that, as the operating point becomes larger, the collector array efficiency decreases. At the contemporary Newnan site it will be recalled that the flow path is changed during the summer months so that air circulates in a tight path between the outlet and inlet of the collector array. The only mechanisms for extracting energy in this flow configuration are the DHW heat exchanger and duct losses. As a result, the collector array inlet temperature becomes very high and the collector array efficiency tends to decrease, even though both the insolation level and the outside ambient temperature also tend to increase in the summer months. The behavior is further illustrated by considering the data in Table 3.2.1-1.

Table 3.2.1-1 presents the monthly values of incident solar energy, operational incident solar energy, and collected solar energy from the 12 month performance period. The collector array efficiency and operational collector array efficiency were computed for each month using Equations (1) and (2). The average operational collector array efficiency was 30 percent compared to a collector array efficiency of 19 percent, which included the effect of the control system. 
CONTEMPCRARY NEWNAN NEWNAN, GEORGIA

COLLEETOR TYPE: CONTEMPORARY SYSTEMSCOLLECTOR YJOEL: SERIES $V$ NARM AIZ

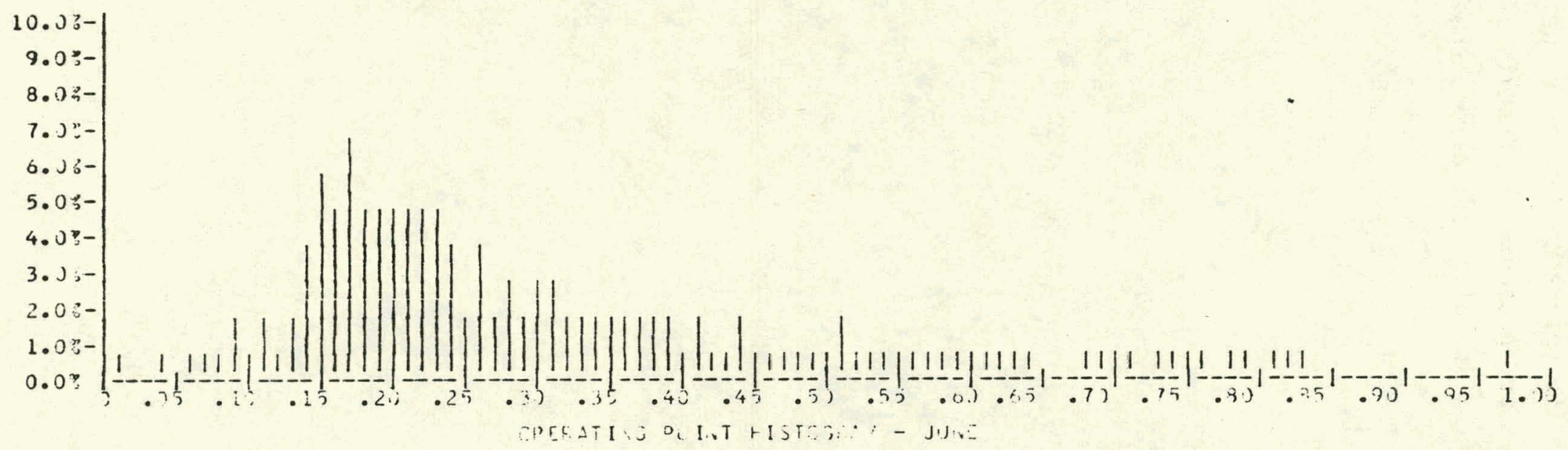

w

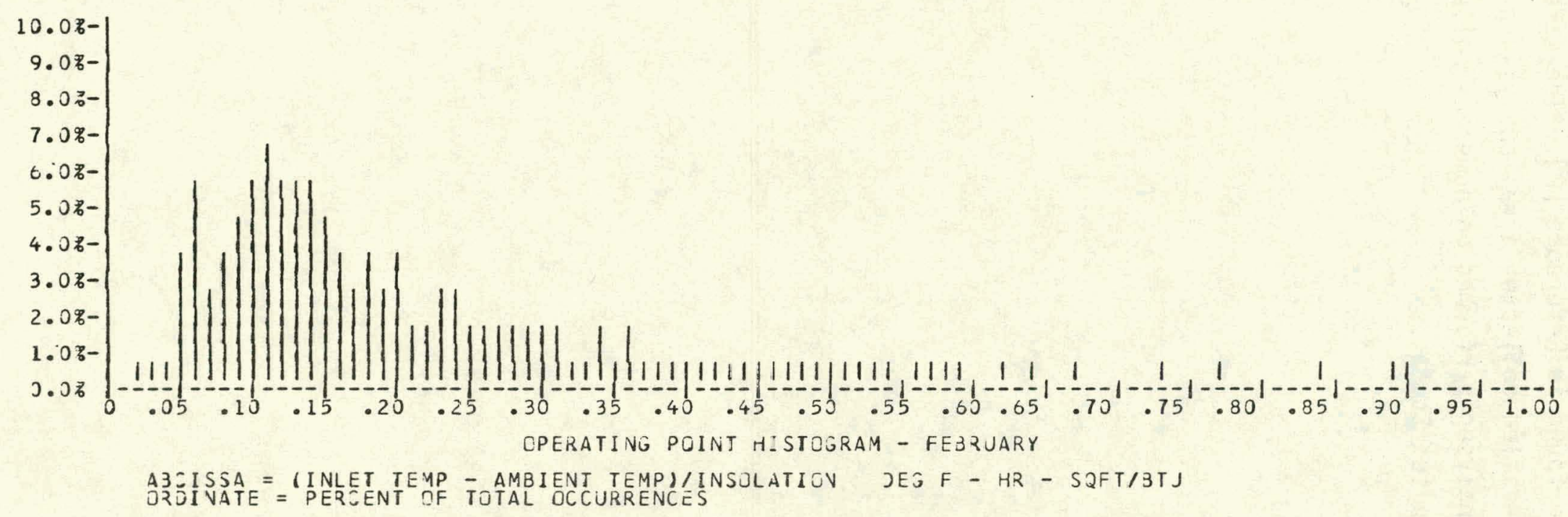

Figure 3.2.1-3 Contemporary Newnan Operating Point Histograms for Typical Winter and Summer Months 
Additional information concerning collector array analysis in general may be found in Reference [8]. The material in the reference describes the detailed collector array analysis procedures and presents the results of analyses performed on numerous collector array installations across the United States. 


\subsubsection{Storage Subsystem}

Storage subsystem performance is described by comparison of energy to storage, energy from storage and change in stored energy. The ratio of the sum of energy from storage and change in stored energy to energy to storage is defined as storage efficiency, $n_{s}$. This relationship is expressed in the equation

$$
n_{s}=\left(\Delta Q+Q_{s 0}\right) / Q_{s i}
$$

where:

$\Delta Q=$ Change in stored energy. This is the difference in the estimated stored energy during the specified reporting period, as indicated by the relative temperature of the storage medium (either positive or negative value)

$Q_{\text {so }}=$ Energy from storage. This is the amount of energy extracted by the load subsystem from the primary storage medium

$Q_{s i}=$ Energy to storage. This is the amount of energy (both solar and auxiliary) delivered to the primary storage medium

Evaluation of the system storage performance under actual system operation and weather conditions can be performed using the parameters defined above. The utility of these measured data in evaluation of the overall storage design are illustrated in the following discussion. 
Table 3.2.2-1 summarizes the storage subsystem performance during the report period. During the eleven month period an approximate total of 23.05 million Btu was delivered to storage and 11.84 million Btu was extracted for support of the space heating load. It should be noted that little or no energy was drawn from storage from June, 1979, through September, 1979, due to the extremely small heating loads during these warm weather months.

The net change in stored energy for the seven months (October through April) in which energy was drawn from storage to supply a significant heating load was -0.02 million Btu. The average storage efficiency over this same period was 0.57 . The average temperature of storage during the heating period was $121^{\circ} \mathrm{F}$ and for the full report period it was $123^{\circ} \mathrm{F}$.

Performance of the Contemporary Newnan storage subsystem was notably superior to the Contemporary Manchester storage subsystem, in terms of both storage efficiency and average storage temperature, giving a heating season storage efficiency of 57 percent compared to 48 percent for Manchester and an average temperature of $121^{\circ} \mathrm{F}$ versus Manchester's $88^{\circ} \mathrm{F}$. The Newnan storage subsystem also showed good stratification properties as illustrated in Figure 2.1-1. 
TABLE 3.2.2-1

STORAGE SUBSYSTEM PERFORMANCE

\begin{tabular}{|c|c|c|c|c|c|c|}
\hline \multirow{4}{*}{$=$} & Month & $\begin{array}{l}\text { Energy To } \\
\text { Storage } \\
\text { (Million Btu) }\end{array}$ & $\begin{array}{l}\text { Energy From } \\
\text { Storage } \\
\text { (Million Btu) }\end{array}$ & $\begin{array}{l}\text { Change In } \\
\text { Stored } \\
\text { Energy } \\
\text { (Million Btu) }\end{array}$ & $\begin{array}{c}\text { Storage } \\
\text { Efficiency }\end{array}$ & $\begin{array}{l}\text { Storage } \\
\text { Average } \\
\text { Temperature } \\
{ }^{\circ} \mathrm{F}\end{array}$ \\
\hline & Jun 79 & 0.915 & 0.000 & 0.187 & 0.20 & 143 \\
\hline & Jul 79 & 0.677 & 0.000 & 0.077 & 0.11 & 136 \\
\hline & Aug 79 & 0.001 & 0.000 & -0.022 & 0.00 & 107 \\
\hline \multirow[t]{3}{*}{ - } & Sep 79 & 0.722 & 0.007 & 0.431 & 0.61 & 118 \\
\hline & Oct 79 & 3.642 & 1.724 & 0.116 & 0.51 & 146 \\
\hline & Nov 79 & 2.713 & 1.517 & -0.278 & 0.46 & 134 \\
\hline \multirow[t]{7}{*}{$\boldsymbol{\omega}$} & Dec 79 & 3.299 & 2.475 & -0.182 & 0.70 & 105 \\
\hline & Jan 80 & 1.911 & 1.192 & 0.029 & 0.64 & 96 \\
\hline & Feb 80 & 3.310 & 1.929 & 0.333 & 0.68 & 107 \\
\hline & Mar 80 & 3.263 & 2.003 & -0.025 & 0.61 & 121 \\
\hline & Apr 80 & 2.600 & 0.988 & -0.008 & 0.38 & 139 \\
\hline & Total & 23.053 & 11.835 & $-0.015 *$ & -- & -- \\
\hline & Average & 2.10 & 1.08 & $-0.002 *$ & 0.57 * & 123 \\
\hline
\end{tabular}

* Storage efficiency and change in stored energy obtained by considering only the seven months in which energy was drawn from storage to supply a significant heating load. 


\subsubsection{Hot Water Subsystem}

The performance of the hot water subsystem is described by comparing the amount of solar energy supplied to the subsystem with the energy required to satisfy the total hot water load. The energy required to satisfy the total load consists of both solar energy and auxiliary thermal energy.

The performance of the Contemporary Newnan hot water subsystem is presented in Table 3.2.3-1. The value for auxiliary energy supplied in Table 3.2.3-1 is the gross energy supplied to the auxiliary system. In the case of Contemporary Newnan, where the hot water auxiliary energy is supplied by electric resistance elements, an efficiency of one is assumed and the values of auxiliary energy and auxiliary thermal energy (energy delivered to the load) are the same. The difference between the sum of auxiliary thermal plus solar energy and the hot water load is equal to the thermal (standby) losses from the hot water subsystem.

The measured solar fraction in Table 3.2.3-1 is an average weighted value for the month based on the ratio of solar energy in the hot water tank to the total energy in the hot water tank when a demand for hot water exists. This value is dependent on the dally profile of hot water usage. It does not represent the ratio of solar energy supplied to the sum of solar plus auxiliary thermal energy supplied shown in the table.

For the eleven month period from June, 1979, through Aprii, 1980, the solar energy system supplied a total of 3.79 million Btu to the hot water subsystem. Auxiliary energy supplied over this period amounted to 6.45 million Btu yielding a total (solar plus auxiliary) input of 10.24 million Btu. The hot water load for the report period was 8.69 million Btu giving a total thermal (standby) loss of 1.55 million Btu. 
TABLE 3.2.3-1

HOT WATER SUBSYSTEM PERFORMANCE 、

\begin{tabular}{|c|c|c|c|c|c|c|c|c|}
\hline \multirow[b]{2}{*}{ Month } & \multicolumn{4}{|c|}{ Hot Water Parameters } & \multicolumn{3}{|c|}{$\begin{array}{l}\text { Energy Consumed } \\
\text { (Milition Btu) }\end{array}$} & \multirow{2}{*}{$\begin{array}{l}\text { Weighted } \text { ** } \\
\text { Solar } \\
\text { Fraction } \\
\text { (Percent) }\end{array}$} \\
\hline & $\begin{array}{c}\text { Load } \\
\text { (Million Btu }\end{array}$ & $\begin{array}{l}\text { Gallons } \\
\text { Used }\end{array}$ & \multicolumn{2}{|c|}{ Temperatures $\left({ }^{\circ} \mathrm{F}\right)$} & Solar & $\begin{array}{r}\text { Auxiliary } \\
\text { Thermal }\end{array}$ & Auxiliary & \\
\hline Jun 79 & 0.000 & 0 & 84 & 94 & 0.220 & 0.111 & 0.111 & 15 \\
\hline Jul 79 & 0.200 & 682 & 72 & 103 & 0.154 & 0.069 & 0.069 & 20 \\
\hline Aug 79 & 0.001 & 28 & 82 & 87 & 0.003 & 0.000 & 0.000 & 12 \\
\hline Sep 79 & 0.000 & 5 & 76 & 75 & 0.091 & 0.000 & 0.000 & 37 \\
\hline Oct 79 & 0.224 & 598 & 79 & 83 & 0.275 & 0.121 & 0.121 & 48 \\
\hline Nov 79 & 1.087 & 2673 & 74 & 93 & 0.563 & 0.733 & 0.733 & 29 \\
\hline Dec 79 & 1.315 & 2851 & 58 & 116 & 0.424 & 1.016 & 0.016 & 29 \\
\hline Jan 80 & 1.604 & 3311 & 55 & 116 & 0.273 & 1.416 & 1.416 & 15 \\
\hline Feb 80 & 1.532 & 3059 & 52 & 116 & 0.541 & 1.185 & 1.185 & 29 \\
\hline Mar 80 & 1.435 & 2914 & 54 & 116 & 0.586 & 1.011 & 1.011 & 35 \\
\hline Apr 80 & 1.287 & 2809 & 60 & 116 & 0.661 & 0.790 & 0.790 & 45 \\
\hline Total & 8.685 & 18930 & -- & -- & 3.791 & 6.452 & 6.452 & -- \\
\hline Average & 0.79 & $172]$ & 68 & 101 & 0.34 & 0.59 & 0.59 & $0.30 *$ \\
\hline
\end{tabular}

* Average solar fraction for the reporting period is weighted by the hot water load.

**. Monthly solar fraction is computed (weighted) at the time hot water is actually used. 
It should be noted from Table 3.2.3-1 that the hot water load for the months of June, August, and September, 1979, was negligible due to the unoccupied status of the house. The small usage in July, 1979, was due to the use of hot water for cleaning vinyl siding and for other cleaning purposes. To provide a more realistic hot water load, an automatic hot water load simulator was installed at the site in 0ctober, 1979. This device was removed, on or about, November 15, 1979, when the house became occupied and the hot water load, from that point to the end of the report period, represents actual usage by the occupants. Because of the erratic pattern of hot water usage over the report period, the overall average solar fraction for the period of 30 percent was obtained by weighting the hot water solar fraction for each month by the hot water load for that month. 


\subsubsection{Space Heating Subsystem}

The performance of the space heating subsystem is described by comparing the amount of solar energy supplied to the subsystem with the energy required to satisfy the total space heating load. The energy required to satisfy the total load consists of both solar energy and auxiliary thermal energy. The ratio of solar energy supplied to the load to the total load is defined as the heating solar fraction. The calculated heating solar fraction is the indicator of performance for the subsystem because it defines the percentage of the total space heating load supported by solar energy.

The performance of the Contemporary Newnan space heating subsystem is presented in Table 3.2.4-1. For the 11 month period from June, 1979 through April, 1980, the solar energy system supplied a measured total of 10.75 million Btu to the space heating load. The total measured heating load for this period was 23.06 million Btu and the average monthly solar fraction was 47 percent.

In assessing the performance of the space heating, subsystem it should be noted that there are limitations of the instrumentation system which preclude the direct measurement of system losses. Measurement of space heating load, solar and auxiliary contributions and solar fraction are based on "delivered energy," therefore, losses must be computed from the difference between delivered energy and collected energy. The solar energy losses are significant, however, because the majority of such losses are added to the interior of the house and represent an uncontrolled contribution to the space heating load. At the Contemporary Newnan site the solar energy losses occur during energy transport between the various subsystems (primarily due to direct leakage), from the rock storage unit and, to a lesser extent, the hot water preheat tank. During the heating season (October, 1979 through Apri1, 1980) a total of approximately 11.38 million Btu of solar energy was added to the interior of the house through these losses. Thus, the energy added to the heated space due to solar 
system losses was approximately 106 percent greater than the measured amount of solar energy supplied during the heating season in the intended operating modes.

'A calculation which treats these losses as a positive contribution to the space heating requirements, results in a higher solar fraction than that determined by the measured data. If solar losses are added to the space heating load and to the solar contribution, the heating solar fraction increases to 64 percent.

During the 11 month reporting period a total of 12.31 million Btu of auxiliary thermal energy was supplied to the space heating load by the heat pump. The auxiliary electrical energy input to the heat pump over this period amounted to 3.41 million Btu, giving an overall Coefficient of Performance (COP) of 3.61 for the heat pump. 
TABLE 3.2.4-1

HEATING SLBBSYSTEM PERFORMANCE

\begin{tabular}{|c|c|c|c|c|c|c|c|}
\hline \multirow[b]{3}{*}{ Month } & \multicolumn{3}{|c|}{ Heating Parameters } & \multicolumn{3}{|c|}{$\begin{array}{c}\text { Energy Consumed } \\
\text { (Million Btu) }\end{array}$} & \multirow{3}{*}{$\begin{array}{l}\text { Measured } \\
\text { Solar } \\
\text { Fraction } \\
\text { (Percent) }\end{array}$} \\
\hline & \multirow{2}{*}{$\begin{array}{l}\text { Load } \\
\text { (Million Btu) }\end{array}$} & \multicolumn{2}{|c|}{ Temperatures $\left({ }^{\circ} \mathrm{F}\right)$} & \multirow[b]{2}{*}{ Solar } & \multirow{2}{*}{$\begin{array}{l}\text { Auxiliary } \\
\text { Thermal }\end{array}$} & \multirow[b]{2}{*}{ Auxiliary } & \\
\hline & & Building & Outdoor & & & & \\
\hline Jun 79 & 0.056 & 76 & 74 & 0.000 & 0.056 & 0.019 & 0 \\
\hline Jul 79 & 0.047 & 80 & 77 & 0.000 & 0.047 & 0.016 & 0 \\
\hline Aug 79 & 0.111 & 82 & 77 & 0.000 & 0.111 & 0.037 & 0 \\
\hline Oct 79 & 1.255 & 71 & 59 & 1.255 & 0.0 & 0.0 & 100 \\
\hline Nov 79 & 1.294 & 69 & 50 & 1.294 & 0.0 & 0.0 & 100 \\
\hline Dec 79 & 5.011 & 68 & 43 & 2.409 & 2.602 & 0.730 & 48 \\
\hline Jan 80 & 5.508 & 67 & 43 & 1.125 & 4.383 & 1.060 & 20 \\
\hline Feb 80 & 5.740 & 66 & 40. & 2.171 & 3.569 & 1.020 & 38 \\
\hline Mar 80 & 2.942 & 68 & 50 & 1.670 & 1.272 & 0.440 & 57 \\
\hline Total & 23.067 & -- & -- & 10.754 & 12.307 & 3.409 & -- \\
\hline Average & 2.10 & 72 & 58 & 0.98 & 0.98 & 1.12 & $47 \star$ \\
\hline
\end{tabular}

* Average solar fraction is the ratio of Total Solar Energy to Total Load 


\section{Operating Energy}

Operating energy for the Contemporary Newnan Solar Energy System is defined as the energy required to transport solar energy to the point of use. Total operating energy for this system consists of Energy Collection and Storage Subsystem (ECSS) operating energy, hot water subsystem operating energy and space heating subsystem operating energy. Operating energy is electrical energy that is used to support the subsystems without affecting their thermal state. Measured monthly values for subsystem operating energy are presented in Table 4-1.

Total system operating energy for the Contemporary Newnan Solar Energy System is that electrical energy required to operate the blower in the main air handler unit, the pump in the DHW subsystem and the indoor and outdoor fans in the auxiliary (heat pump) subsystem. These are shown as EP400, EP300, a portion of EP401, respectively, in Figure 2-1. Although additional electrical energy is required to operate motor driven dampers and the control system for the installation, it is not included in this report. These devices are not monitored for power consumption and the power they consume is insignificant when compared to the fan and pump motors.

During the 11 month reporting period, a total of 4.40 million Btu (1290 kWh) of operating energy was consumed. However, this energy includes that portion of the energy required by the blower in the main air handler unit when the blower is distributing air to the heated space (space heating operating energy). That energy would be required whether or not the solar energy system was present, therefore, it is not considered solar peculiar.

A total of 2.24 million Btu (656 kWh) of operating energy was required to support the blower and pump when the solar collection and storage subsystems were active. Of this total 1.82 million Btu were allocated to the Energy Collection and Storage Subsystem (ECSS) and 0.42 million Btu to the DHW subsystem. Since a measured 14.54 million Btu of solar energy was delivered to system loads during the reporting period, a total of 0.15 million Btu ( $45 \mathrm{kWh}$ ) of operating energy was required for each one million Btu of solar energy delivered to the system loads. 
TA.BLE 4-1

OPERATING ENERGY

\begin{tabular}{|c|c|c|c|c|}
\hline Month & $\begin{array}{c}\text { ECSS } \\
\text { Operating Energy } \\
\text { (Million Btu) }\end{array}$ & $\begin{array}{c}\text { Hot Water } \\
\text { operating Energy } \\
\text { (Million Btu) }\end{array}$ & $\begin{array}{c}\text { Space Heating } \\
\text { Operating Energy } \\
\text { (Million Btu) }\end{array}$ & $\begin{array}{c}\text { Total System } \\
\text { Operating Energy } \\
\text { (Million Btu) }\end{array}$ \\
\hline Jun 79 & 0.185 & 0.026 & 0.008 & 0.219 \\
JuT 79 & 0.131 & 0.020 & 0.001 & 0.152 \\
Aug 79 & 0.000 & 0.032 & 0.085 & 0.117 \\
Sep 79 & 0.098 & 0.019 & 0.168 & 0.285 \\
Oct 79 & 0.261 & 0.029 & 0.039 & 0.329 \\
Nov 79 & 0.211 & 0.050 & 0.086 & 0.347 \\
Dec 79 & 0.194 & 0.045 & 0.399 & 0.638 \\
Jan 80 & 0.113 & 0.030 & 0.563 & 0.706 \\
Feb 80 & 0.200 & 0.054 & 0.579 & 0.833 \\
Mar 80 & 0.208 & 0.054 & 0.203 & 0.465 \\
Apr 80 & 0.221 & 0.061 & 0.030 & 0.312 \\
\hline Totaj & 1.822 & 0.420 & 2.161 & 4.403 \\
\hline Average & 0.17 & 0.04 & 0.20 & 0.40 \\
\hline
\end{tabular}




\section{ENERGY SAVINGS}

Solar energy system savings are realized whenever energy provided by the solar energy system is used to meet demands which would otherwise be met by auxiliary energy sources. The operating energy required to provide solar energy to the load subsystems is subtracted from the solar energy contributions to obtain the net savings attributed to the use of solar energy.

Energy savings for the 11 month reporting period are presented in Table 5-1. Hot water savings for the report period totaled 2.31 million Btu and, in the computation of this value the energy required to operate the pump in the DHW preheat loop has been subtracted. The computation of electrical savings for space heating uses an assumed coefficient of performance (COP) of 2.0 for the heat pump and subtracts that portion of the heating operating energy which is required when solar heat is provided to the heated space from the collectors or from the storage bin. As seen from Table 5-1. the adjusted value of electrical savings for the report period was 4.99 million Btu. Adding the adjusted values of 2.31 million Btu for hot water and 4.99 million Btu for space heating gives a gross electrical savings of 7.3 million Btu. The total ECSS operating energy of 1.82 million Btu is subtracted, giving a total net electrical savings of 5.47 million Btu (1603 kWh) for the report period.

It should be noted that all values relating to space heating savings are based only on the measured solar energy contribution to the space heating load. As discussed in the Space Heating Subsystem section, approximately 11.38 million Btu of solar energy were added to the interior of the house through various losses during the heating season. This uncontrolled addition of solar energy to the house, had it been included in the space heating subsystem computations, would have increased the space heating (and total system) savings significantly. This additional, but unreported, savings can be approximated by applying the assumed heat pump COP of 2 which gives an adjusted gross space heating savings of an additional 5.69 million Btu. This computation results in a revised net electrical savings of 11.16 million Btu (3270 kWh), approximately twice the reported value of 5.47 million Btu (1603 kWh). 
TABLE 5-1

ENERGY SAVINGS

\begin{tabular}{|c|c|c|c|c|c|c|}
\hline \multirow[b]{2}{*}{ Month } & \multicolumn{2}{|c|}{$\begin{array}{l}\text { Electrical } \\
\text { Energy Savings } \\
\text { (Million Btu) }\end{array}$} & \multirow{2}{*}{$\begin{array}{c}\text { ECSS } \\
\text { Operating } \\
\text { Energy } \\
\text { (Million Btu) }\end{array}$} & \multicolumn{2}{|c|}{$\begin{array}{l}\text { Net } \\
\text { Electrica1 Energy } \\
\text { Savings }\end{array}$} & \multirow{2}{*}{$\begin{array}{l}\text { Fossil } \\
\text { Equivalent } \\
\text { At Source } \\
\text { (Million Btu) }\end{array}$} \\
\hline & Water & Heating & & Million Btu) & (kWh) & \\
\hline Jun 79 & -0.026 & 0.000 & 0.185 & -0.211 & -61.8 & -0.703 \\
\hline Ju1 79 & -0.002 & 0.000 & 0.131 & -0.133 & -38.9 & -0.443 \\
\hline Aug 79 & -0.025 & 0.000 & 0.000 & -0.025 & -7.3 & -0.083 \\
\hline Sep 79 & -0.018 & -0.001 & 0.098 & -0.117 & -34.3 & -0.390 \\
\hline Oct 79 & 0.102 & 0.597 & 0.261 & 0.439 & 128.5 & 1.463 \\
\hline Nov 79 & 0.383 & 0.602 & 0.211 & 0.774 & 226.6 & 2.580 \\
\hline Dec 79 & 0.326 & 1.109 & 0.194 & 1.241 & 363.4 & 4.137 \\
\hline Jan 80 & 0.213 & 0.517 & 0.113 & 0.617 & 180.7 & 2.057 \\
\hline Feb 80 & 0.383 & 1.005 & 0.200 & 1.188 & 347.8 & 3.960 \\
\hline Mar 80 & 0.458 & 0.776 & 0.208 & 1.026 & 300.4 & 3.420 \\
\hline Apr 80 & 0.512 & 0.383 & 0.221 & 0.674 & 197.3 & 2.247 \\
\hline Total & 2.306 & 4.988 & 1.822 & 5.473 & 1602.4 & 18.245 \\
\hline Average & 0.21 & 0.45 & 0.17 & 0.50 & 145.7 & 1.66 \\
\hline
\end{tabular}




\section{MAINTENANCE}

Significant maintenance activities carried out at the Contemporary Newnan site during the report period are summarized below:

September 7, 1979 - Repair of Duct Leak

Site data indicated a significant reduction in storage bin input and output air flow values ( $W 200$ and $W 201$ ). Site inspection revealed sizable hole in duct (probably due to removal of an air measurement probe). The hole was repaired by the installing contractor and flow values returned to normal.

\section{September 7, 1979 - Correction of Control Relay Chatter}

During the months of June, July and August, numerous adjustments in the mode of operation were made in an attempt to resolve a solar system relay chattering problem that prevented operation of the auxiliary system in the air conditioning mode. Investigation revealed an unsoldered connection to the transformer in the Logic Control Unit (LCU). Repair of this connection apparently solved the malfunction due to relay chatter.

November 10, 1979 - Removal of Hot Water Auto-Load Uevice

The automatic hot water load simulator was removed in preparation for the house becoming occupied, on or about, November 15, 1979. 


\section{SUMMARY AND CONCLUSIONS}

The following paragraphs provide a brief summary of all pertinent parameters for the Contemporary Newnan Solar Energy System for the period from June, 1979, through Apri1, 1980. A more detailed discussion can be found in the preceding sections.

During the reporting period, the measured daily average insolation in the plane of the collector array was 1,265 Btu/ $\mathrm{ft}^{2}$. This was 11 percent below the long-term daily average of $1,414 \mathrm{Btu} / \mathrm{ft}^{2}$. During the same period the measured average outdoor ambient temperature was $58^{\circ} \mathrm{F}$. This was three degrees below the long-term average of $61^{\circ} \mathrm{F}$. As a result of the lower average temperature, 3392 heating degree-days were accumulated which is 17 percent above the long-term value of 2889 heating degreedays. In view of the increased number of heating degree-days and reduced average value of incident solar energy, over the report period, climatic conditions had an adverse effect on the performance of the solar energy system.

The solar energy system satisfied 42 percent of the total measured load (hot water plus space heating) during the 11 month reporting period. This value was somewhat higher than the expected solar fraction of 32 percent obtained from the f-Chart analysis. As noted in Section 3.2.4, when system losses into the heated space from duct leaks, storage etc. are included, the heating solar fraction increases from 42 percent to 64 percent which, in turn, will increase the overall system solar fraction.

A total of 165.98 million Btu of incident solar energy was measured in the plane of the collector during the reporting period. The system collected 30.76 million Btu of the available energy, which represents a collector array efficiency of 19 percent. During periods when the collector array was active, a total of 100.92 million Btu was measured in the plane of the collector array. Therefore, the operational collector efficiency was 30 percent. 
During the reporting period a total of 23.05 million Btu was delivered to the storage bin. During the same time, 11.84 million Btu were removed from storage for support of the space heating load. In the period from June, 1979, through September, 1979, there was no energy output from storage because the heating load was negligibly small. For this reason, the computation of storage efficiency was based on the seven month period (October through Apri1) when energy from storage was used to support a significant heating load. On this basis, the storage efficiency was computed to be 57 percent. During this same period the net change in stored energy was -0.02 million Btu and 11.2 million Btu were lost from storage. The average storage temperature was $121^{\circ} \mathrm{F}$ during the active period and $123^{\circ} \mathrm{F}$ over the full report period.

The hot water load for the 11 month reporting period was 8.69 million Btu. A total of 3.79 million Btu of solar energy and 6.45 million Btu of auxiliary thermal energy were supplied to the hot water subsystem. $A$ total of 1.55 million Btu of the energy delivered to the hot water subsystem was dissipated as standby losses. The weighted hot water solar fraction (computed when hot water is actually used) for the report period was 30 percent and the average hot water delivery temperature was $101^{\circ} \mathrm{F}$. This delivery temperature is artificially low because of the unoccupied status of the house from June, 1979, through October, 1979 and resultant low or sporadic hot water usage. An average temperature of $112^{\circ} \mathrm{F}$, computed for the six months when the house was occupied, is considered a more realistic measure of hot water system performance.

The measured space heating load was 23.06 million Btu for the 11 month reporting period. Ninety eight percent of the heating load $(22.60$ million Btu) occurred during the primary heating season; 0ctober, 1979, through April, 1980. The heating solar fraction for the 11 month period was 47 percent with solar energy supplying 10.75 million Btu and the heat pump supplying 12.31 million Btu of auxiliary thermal energy. The space heating subsystem maintained an average building temperature of $72^{\circ} \mathrm{F}$ during the report period. 


\begin{abstract}
A total of 2.24 million Btu, or $657 \mathrm{kWh}$ of electrical operating energy was required to support the Contemporary Newnan Solar Energy System during the 11 month reporting period.
\end{abstract}

The net electrical energy savings for the 11 month report period were 5.47 million Btu, or the equivalent of $1602 \mathrm{kWh}$, or 0.9 barrels of oil. It should be noted that the energy savings are based only on the measured amount of solar energy delivered to the space heating subsystem. As discussed in Section 5, the energy savings approximately double if the uncontrolled solar energy input (losses into the heated space) is considered. 


\section{REFERENCES}

1. DOE/NASA CR-161228, Solar Heating System Final Design Package, May, 1979.

2. DOE/NASA CR-150600, Design Data Brochure For CSI Series V Solar Heating System, January, 1978.

3. DOE/NASA CR-161229, System Installation Package For the New Hampshire Vocational Technical College, Manchester, NH, May, 1979.

4. J.'T. Smok, V. S. Sohoni, J. M. Nash, "Processing of Instrumented Data for the National Solar Heating and Cooling Demonstration Program," Conference on Performance Monitoring Techniques for

- Evaluation of Solar Heating and Cooling Systems, Washington; D.C., April, 1978.

5. E. Streed, etc. al., Thermal Data Requirements and Performance Evaluation Procedures for the Natinnal Solar Heating and Cooling Demonstration Program, NBSIR-76-1137, National Bureau of Standards, Washington, D.C., August, 1976.

6. ASHRAE Standard 93-77, Methods of Testing to Determine the Thermal Performance of Solar collectors, The Allerican Society of Heating, Refrigeration and Air Conditioning Engineers, Inc., New York, NY, 1977.

7. ASHRAE Standard 94-77, Methods of Testing Thermal Storage Devices Based on Thermal Performance, The American Society of Heating, Refrigeration and Air Conditioning Engineers, Inc:, New, York, NY, 1977.

9

8. McCumber, W. II. Jr., "Collector Array Performance for Instrumented Sites of the National Solar Heating and Cooling Demonstration Program," published and distributed at the 1979 Solar Up-Date Conference.

9. Beckman, William A.; Klein, Sanford A.; Duffic, John A., Solar Heating Design by the f-Chart Method, John Wiley and Sons, New York, NY, 1977. 


\section{APPENDIX A \\ DEFINITION OF PERFORMANCE FACTORS \\ AND \\ SOLAR TERMS}

$A-1$ 
APPENDIX A

DEFINITION OF PERFORMANCE FACTORS AND SOLAR TERMS

\section{COLLECTOR ARRAY PERFORMANCE}

The collector array performance is characterized by the amount of solar energy collected with respect to the energy available to be collected.

- INCIDENT SOLAR ENERGY (SEA) is the total insolation available on the gross collector array area. This is the area of the collector array energy-receiving aperture, including the framework which is an integral part of the collector structure.

- OPERATIONAL INCIDENT ENERGY (SEOP) is the amount of solar energy incident on the collector array during the time that the collector loop is active (attempting to collect energy).

- COLLECTED SOLAR ENERGY (SECA) is the thermal energy removed from the collector array by the energy transport medium.

- COLLECTOR ARRAY EFFICIENCY (CAREF) is the ratio of the energy collected to the total solar energy incident on the collector array. It should be emphasized that this efficiency factor is for the collector array, and available energy includes the energy incident on the array when the collector loop is inactive. This efficiency must not be confused with the more common collector efficiency figures which are determined from instantaneous test data obtained during steady state operation of a single collector unit. These efficiency figures are often provided by collector manufacturers or presented in technical journals to characterize the functional capability of a particular collector design. In general, the collector panel maximum efficiency factor will be significantly higher than the reported collector array efficiency. 
The Energy Collection and Storage Subsystem (ECSS) is composed of the collector array, the primary storage medium, the transport 10ops between these, and other components in the system design which are necessary to mechanize the collector and storage equipment.

- INCIDENT SOLAR ENERGY (SEA) is the total insolation available on the gross collector array area. This is the area of the collector array energy-receiving aperture, including the framework which is an integral part of the collector structure.

- AMBIENT TEMPERATURE (TA) is the average temperature of the outdoor environment at the site.

- ENERGY TO LOADS (SEL) is the total thermal energy transported from the ECSS to all load subsystems.

- AUXILIARY THERMAL ENERGY TO ECSS (CSAUX) is the total auxiliary supplied to the ECSS, including auxiliary energy added to the storage tank, heating devices on the collectors for freezeprotection, etc.

- ECSS OPERATING ENERGY (CSOPE) is the critical operating energy required to support the ECSS heat transfer loops. 


\section{STORAGE PERFORMANCE}

The storage performance is characterized by the relationships among the energy delivered to storage, removed from storage, and the subsequent change in the amount of stored energy.

- ENERGY TO STORAGE (STEI) is the amount of energy, both solar and auxiliary, delivered to the primary storage medium.

- ENERGY FROM STORAGE (STEO) is the amount of energy extracted by the load subsystems from the primary storage medium.

- CHANGE IN STORED ENERGY (STECH) is the difference in the estimated stored energy during the specified reporting period, as indicated by the relative temperature of the storage medium (either positive or negative value).

- STORAGE AVERAGE TEMPERATURE (TST) is the mass-weighted average temperature of the primary storage medium.

- STORAGE EFFICIENCY (STEFF) is the ratio of the sum of the energy removed from storage and the change in stored energy to the energy delivered to storage. 
HOT WATER SUBSYSTEM

The hot water subsystem is characterized by a complete accounting of the energy flow to and from the subsystem, as well as an accounting of internal energy. The energy into the subsystem is composed of auxiliary fossil fuel, and electrical auxiliary thermal energy, and the operating energy for the subsystem. In addition, the solar energy supplied to the subsystem, along with solar fraction is tabulated. The load of the subsystem is tabulated and used to compute the estimated electrical and fossil fuel savings of the subsystem. The load of the subsystem is further identified by tabulating the supply water temperature, and the outlet hot water temperature, and the total hot water consumption.

- HOT WATER LOAD (HWL) is the amount of energy required to heat the amount of hot water demanded at the site from the: incoming temperature to the desired outlet temperature.

- SOLAR FRACTION OF LOAD (HWSFR) is the percentage of the load demand which is supported by solar energy.

- SOLAR ENERGY USED (HWSE) is the amount of solar energy supplied to the hot water subsystem.

- OPERATING ENERGY (HWOPE) is the amount of electrical energy required to support the subsystem, (e.g., fans, pumps, etc.) and which is not intended to directly affect the thermal state of the subsystem.

- AUXILIARY THERMAL USED (HWAT) is the amount of energy supplied to the major components of the subsystem in the form of thermal energy in a heat transfer fluid, or its equivalent. This term also includes the converted electrical and fossil fuel energy supplied to the subsystem. 
- AUXILIARY ELECTRICAL FUEL (HWAE) is the amount of electrical energy supplied directly to the subsystem.

- ELECTRICAL ENERGY SAVINGS (HWSVE) is the estimated difference between the electrical energy requirements of an alternative conventional system (carrying the full load) and the actual electrical energy required by the subsystem.

- SUPPLY WATER TEMPERATURE (TSW) is the average inlet temperature of the water supplied to the subsystem.

- AVERAGE HOT WATER TEMPERATURE (THW) is the average temperature of the outlet water as it is supplied from the subsystem to the load.

- HOT WATER USED (HWCSM) is the volume of water used. 


\section{ENVIRONMENTAL SUMMARY}

The environmental summary is a collection of the weather data which is generally instrumented at each site in the Development Program. It is tabulated in this report for two purposes (1) as a measure of the conditions prevalent during the operation of the system at the site, and (2) as a historical record of weather data for the vicinity of the site.

- TOTAL INSOLATION (SE) is the accumulated total solar energy incident upon the gross collector array measured at the site.

- AMBIENT TEMPERATURE (TA) is the average temperature of the environment at the site.

- DAYTIME AMBIENT TEMPERATURE (TDA) is the temperature during the period from three hours before solar noon to three hours after solar noon. 
APPENDIX B

SOLAR ENERGY SYSTEM PERFORMANCE EQUATIONS FOR

CONTEMPORARY NEWNAN

B-1 
APPENDIX B

\section{SOLAR ENERGY SYSTEM PERFORMANCE EQUATIONS FOR \\ CONTEMPORARY MANCHESTER}

\section{INTRODUCTION}

Solar energy system performance is evaluated by performing energy balance calculations on the system and its major subsystems. These calculations are based on physical measurement data taken from each subsystem every 320 seconds. This data is then numerically combined to determine the hourly, daily, and monthly performance of the system. This appendix describes the general computational methods and the specific energy balance equations used for this evaluation.

Data samples from the system measurements are numerically integrated to provide discrete approximations of the continuous functions which characterize the system's dynamic behavior. This numerical integration is performed by summation of the product of the measured rate of the appropriate performance parameters and the sampling interval over the total time period of interest.

There are several general forms of numerical integration equations which are applied to each site. Examples of these general forms are as follows: The total solar energy available to the collector array is given by

SOLAR ENERGY AVAILABLE $=(1 / 60) \ddot{\Sigma}[1001 \times$ AREA $] \times \Delta \tau$

Where 1001 is the solar radiation measurement provided by the pyranometer in Btu/ft $\mathrm{ft}^{2}-\mathrm{hr}$, AREA is the area of the collector array in square feet, $\Delta \tau$ is the sampling interval in minutes, and the factor (1/60) is included to correct the solar radiation "rate" to the proper units of time. 
Similarly, the energy flow within a system is given typically by

$$
\text { COLLECTED SOLAR ENERGY }=\Sigma[M T 00 \times \Delta H] \times \Delta \tau
$$

where M100 is the mass flow rate of the heat transfer fluid, in $1 \mathrm{~b}_{\mathrm{m}} / \mathrm{min}$, and $\Delta H$ is the enthalpy change, in $B t u / l b_{m}$, of the fluid as it passes through the heat exchanging component.

For a liquid system $\Delta H$ is generally given by

$$
\Delta H=\bar{C}_{p} \Delta T
$$

where $\bar{C}_{p}$ is the average specific heat, in $B t u /\left(1 b_{m}-{ }^{\circ} F\right)$, of the heat transfer fluid and $\Delta T$, in ${ }^{\circ} \mathrm{F}$, is the temperature differential across the heat exchanging component.

For an air system $\Delta H$ is generally given by

$$
\Delta H=H_{a}\left(T_{\text {out }}\right)-H_{a}\left(T_{\text {in }}\right)
$$

where $H_{a}(T)$ is the enthalpy, in $B t u / 1 b_{m}$, of the transport air evaluated at the inlet and outlet temperatures of the heat exchanging component.

$H_{a}(T)$ can have various forms, depending on whether or not the humidity ratio of the transport air remains constant as it passes through the heat exchanging component. 
For electrical power, a general example is

ECSS OPERATING ENERGY $=(3413 / 60) \Sigma[$ EP100] $\times \Delta \tau$

where EP100 is the measured power required by electrical equipment in kilowatts and the two factors $(1 / 60)$ and 3413 correct the data to Btu/min.

These equations are comparable to those specified in "Thermal Data Requirements and Performance Evaluation Procedures for the National Solar Heating and Cooling Demonstration Program." This document, given in the list of references, was prepared by an inter-agency committee of the government, and presents guidelines for thermal performance evaluation.

Performance factors are computed for each hour of the day. Each numerical integration process, therefore, is performed over a period of one hour. Since long-term performance data is-desired, it is necessary to build these hourly performance factors to daily values. This is accomplished, for energy parameters, by summing the 24 hourly values. For temperatures, the hourly values are averaged. Certain special factors, such as efficiencies, require appropriate handling to properly weight each hourly sample for the daily value computation. Similar procedures are required to convert daily values to monthly values.

\section{PERFORMANCE EQUATIONS}

The performance equations for Contemporary Newnan used for the data evaluation of this report are contained in the following pages and have been included for technical reference and information. 
EQUATIONS USED IN MONTHLY PERFORMANCE ASSESSMENT

NOTE: MEASUREMENT NUMBERS REFERENCE SYSTEM SCHEMATIC FIGURE 2-1

AVERAGE AMBIENT TEMPERATURE $\left({ }^{\circ} \mathrm{F}\right)$

$T A=(1 / 60) \times \Sigma T 001 \times \Delta \tau$

AVERAGE BUILDING TEMPERATURE $\left({ }^{\circ} \mathrm{F}\right)$

$$
\dot{T} \dot{B}=(1 / 60) \times \Sigma(T 600+T 601+T 602) / 3 \times \Delta \tau
$$

DAYTIME AVERAGE AMBIENT TEMPERATURE $\left({ }^{\circ} \mathrm{F}\right)$

$T D A=(1 / 360) \times \Sigma T 001 \times \Delta \tau$

FOR \pm 3 HOURS FROM SOLAR NOON

INCIDENT SOLAR ENERGY PER SQUARE FOOT (BTU/FT ${ }^{2}$ ).

$$
S E=(1 / 60) \times \sum 1001 \times \Delta T
$$

OPERATIONAL INCIDENT SOLAR ENERGY (BTU)

$$
\text { SEOP }=(1 / 60) \times \Sigma[1001 \times \text { CLAREA }] \times \Delta \tau
$$

WHEN THE COLLECTOR LOOP IS ACTIVE

HUMIDITY RATIO FUNCTION (BTU/LBM- ${ }^{\circ} \mathrm{F}$ )

$$
H R F=0.24+0.444 \times H R
$$

WHERE 0.24 IS THE SPECIFIC HEAT AND HR IS THE HUMIDITY RATIO

OF THE TRANSPORT AIR. THIS FUNCTION IS USED WHENEVER THE

HUMIDITY RATIO WILL REMAIN CONSTANT AS THE TRANSPORT AIR FLOWS

THROUGH A HEAT EXCHANGING DEVICE

ENTHALPY FUNCTION FOR WATER (BTU/LBM)

$$
\operatorname{HWD}\left(T_{2}, T_{1}\right)=\int_{T_{1}}^{T_{2}} \quad C_{p}(T) d T
$$

THIS FUNCTION COMPUTES THE ENTHALPY CHANGE OF WATER AS IT PASSES THROUGH A HEAT EXCHANGING DEVICE. 
SOLAR ENERGY COLLECTED BY THE ARRAY (BTU)

$$
\text { SECA }=\Sigma[(\text { M100 } \times(T 150-T 100) \times \text { HRF })]
$$

WHEN THE COLLECTOR LOOP IS ACTIVE

SOLAR ENERGY TO LOAD FROM COLLECTOR ARRAY (BTU)

CSEOHT $=\Sigma[M 401 \times$ HRF $\times(T 401-$ T451) $] \times \Delta \tau$

WHEN HEATING FROM THE COLLECTOR ARRAY

SOLAR ENERGY TO LOAD FROM STORAGE (BTU)

HSEI $=\Sigma[M 401 \times \operatorname{HRF} \times(T 401-T 451)] \times \Delta \tau$

WHEN HEATING FROM STDRAGE

SOLAR ENERGY TO SPACE HEATING SUBSSYYEM (BTU)

HSE $\quad=$ HSEI + CSEOH 1

WHENEVER THE SYSTEM IS HEATING FROM COLLECTORS OR STORAGE HEATING AUXILIARY THERMAL ENERGY TO LOAD (BTU)

HAE $1=56.8833 \times($ EP401 -0.94$)$

HAE2 $=[56.8833 \times($ EP401 -0.28$)]-56.883 \times 4.34$

HAT $=$ (COMPEFF $\times$ HAE 1$)+$ HAE2

WHEN HEATING FROM THE AUXILIARY SOURCE

SPACE HEATING LOAD (BTU)

HL $=H S E+$ HLES + HLHP

WHENEVER THE SYSTEM IS IN A SPACE HEATING MODE

AVERAGE TEMPERATURE OF STORAGE $\left({ }^{\circ} \mathrm{F}\right)$

TST $=(1 / 60) \times(T 201+T 202+T 203) / 3$

SOLAR ENERGY TO STORAGE (BTU)

STEI $=\Sigma[M 200 \times \operatorname{HRF} \times(T 200-T 250)] \times \Delta \tau$

WHEN THE SYSTEM IS IN A STORING HEAT MODE 
SOLAR ENERGY FROM STORAGE (BTU)

STEO $=\Sigma[M 200 \times$ HRF $\times($ T200 - T250)] $\times \Delta \tau$

WHEN THE SYSTEM IS IN HEATING FROM STORAGE MODE

ECSS OPERATING ENERGY (BTU)

CSOPE $=56.8833 \times \Sigma$ EP400 $\times \Delta \tau$

WHEN THE SYSTEM IS IN A STORING HEAT MODE

CSOPE $=56.8833 \times \Sigma(E P 400 / 2) \times \Delta \tau$

WHEN THE SYSTEM IS IN A HEATING FROM COLLECTORS MODE

HOT WATER CONSUMED (GALLONS)

HWCSM $=\sum$ WD301

HOT WATER LOAD

HWL $=\Sigma[M 301 \times \operatorname{HWD}(T 352, T 301)] \times \Delta \tau$

SOLAR ENERGY TO HOT WATER SUBSYSTEM

HWSE $\quad=\quad$ CSEOW $=[M 300 \times H W D(T 350, T 300)] \times \Delta \tau$

SOLAR ENERGY TO HOT WATER LOAD

HWSE $1=\Sigma[M 301 \times \operatorname{HWD}(T 351, T 301)] \times \Delta \tau$

HOT WATER SUBSYSTEM OPERATING ENERGY (BTU)

HWOPE $=56.8833 \times \Sigma$ EP300 $\times \Delta \tau$

HOT WATER SUBSYSTEM AUXILIARY ELECTRICAL FUEL ENERGY (BTU)

HWAE $=56.8833 \times \Sigma$ EP301 $\times \Delta \tau$

SPACE HEATING SUBSYSTEM OPERATING ENERGY (BTU)

HOPEI $=56.8833 \times \Sigma E$ EP400/2 $\times \Delta \tau$

WHEN THE SYSTEM IS IN A HEATING FROM COLLECTORS MODE

HOPEI $=56.8833 \times \Sigma$ EP400 $\times \Delta \tau$

WHEN THE SYSTEM IS IN A HEATING FROM STORAGE MODE

HOPE2 $=56.8833 \times 0.938$ 
SOLAR ENERGY FROM STORAGE (BTU)

STEO $=\Sigma[M 200 \times \operatorname{HRF} \times(T 200-T 250)] \times \Delta \tau$

WHEN THE SYSTEM IS IN HEATING FROM STORAGE MODE

ECSS OPERATING ENERGY (BTU)

CSOPE $=56.8833 \times \Sigma E P 400 \times \Delta \tau$

WHEN THE SYSTEM IS IN A STORING HEAT MODE

CSOPE $=56.8833 \times \Sigma(E P 400 / 2) \times \Delta \tau$

WHEN THE SYSTEM IS IN A HEATING FROM COLLECTORS MODE

HOT WATER CONSUMED (GALLONS)

HWCSM $=\Sigma$ WD301

HOT WATER LOAD

HWL $=\Sigma[M 301 \times \operatorname{HWD}(T 352, T 301)] \times \Delta \tau$

SOLAR ENERGY TO HOT WATER SUBSYSTEM

HWSE $=\quad$ CSEOW $=[M 300 \times \operatorname{HWD}(T 350, T 300)] \times \Delta \tau$

SOLAR ENERGY TO HOT WATER LOAD

HWSE $1=\Sigma[M 301 \times \operatorname{HWD}(T 351, T 301)] \times \Delta \tau$

HOT WATER SUBSYSTEM OPERATING ENERGY (BTU)

HWOPE $=56.8833 \times 2 E$ EP300 $\times \Delta$.

HOT WATER SUBSYSTEM AUXILIARY ELECTRICAL FUEL ENERGY (BTU)

HWAE $=56.8833 \times[E \Gamma 301 \times \Delta \tau$

SPACE HEATING SUBSYSTEM OPERATING ENERGY (BTU)

HOPE $1=56.8833 \times \sum$ EP400/2 $\times \Delta \tau$

WHEN THE SYSTEM IS IN A HEATING FROM COLLECTORS MODE

HOPEI $=56.8833 \times \Sigma E P 400 \times \Delta \tau$

WHEN THE SYSTEM IS IN A HEATING FROM STORAGE MODE

HOPE2 $=56.8833 \times 0.938$

WHEN THE SYSTEM IS IN A HEATING FROM AUXILIARY MODE 
HOPE $=$ HOPE1 + HOPE2

HEATING LOAD SUPPLIED BY AUXILIARY SOURCES

HLHP $=[M 400 \times \operatorname{HRF}(T 401-T 400)] \times \Delta \tau$. (HEAT PUMP)

WHEN AMBIENT TEMPERATURE IS ABOVE $15^{\circ} \mathrm{F}$

HLES $=[M 400 \times \operatorname{HRF}(T 401-T 400)] \times \Delta \tau-$ HLHP

WHEN AMBIENT TEMPERATURE IS BELOW $15^{\circ} \mathrm{F}$

ELECTRICAL ENERGY INPUT TO AUXILIARY SOURCES

HAEHP $=56.8833 \times$ EP401

WHEN THE SYSTEM IS IN A HEATING FROM AUXILIARY MODE

SUPPLY WATER TEMPERATURE $\left({ }^{\circ} \mathrm{F}\right)$

TSW $=\mathrm{T} 301$

HOT WATER TEMPERATURE $\left({ }^{\circ} \mathrm{F}\right)$

THW $=\mathrm{T} 352$

BOTH TSW AND THW ARE COMPUTED ONLY WHEN FLOW EXISTS IN THE SUBSYSTEM, OTHERWISE THEY ARE SET EQUAL TO THE VALUES OBTAINED DURING THE PREVIOUS FLOW PERIOD

INCIDENT SOLAR ENERGY ON COLLECTOR ARRAY (BTU)

SEA $=$ CLAREA $\times$ SE

COLLECTED SOLAR ENERGY PER UNIT AREA (BTU/FT ${ }^{2}$ )

SEC + SECA/CLAREA

COLLECTOR ARRAY EFFICIENCY

CAREF $=$ SECA/SEA

CHANGE. IN STORED ENERGY (BTU)

STECH = STECHI - STECHI $_{p}$

WHERE THE SUBSCRIPT P REFERS TO A PRIOR REFERENCE VALUE STORAGE EFFICIENCY

STEFF $=($ STECH + STEO $) /$ STEI

ENERGY DELIVERED FROM ECSS TO LOAD SUBSYSTEMS (BTU)

CSEO $=$ STEO + CSEOW + CSEOH 
AUXILIARY THERMAL ENERGY TO HOT WATER SUBSYSTEM (BTU)

HWAT = HWAE

HOT WATER SOLAR FRACTION (PERCENT)

HWSFR $=100 \times$ HWTKSE/(HWTKSE + HWTKAUX)

WHERE HWTKSE AND HWTKAUX REPRESENT THE CURRENT SOLAR

AND AUXILIARY ENERGY CONTENT OF THE HOT WATER TANK

HOT WATER ELECTRICAL ENERGY SAVINGS (BTU)

HWSVE $=$ HWSE 1 - HWOPE

SPACE HEATING SUBSYSTEM SOLAR FRACTION (PERCENT)

HSFR $=100 \times \mathrm{HSE} / \mathrm{HL}$

SPACE HEATING SUBSYSTEM ELECTRICAL ENERGY SAVINGS (BTU)

HSVE $=$ HSE/HPCOP - HOPEI

WHERE HPCOP IS THE COEFFICIENT OF PERFORMANCE (COP)

OF THE HEAT PUMP

SYSTEM LOAD (BTU)

SYSL $=H L+H W L$

SOLAR' FRACTION OF SYSTEM LOAD (PERCENT)

SFR $=(H L \times H S F R+H W L \times H W S F R) / S Y S L$

SYSTEM OPERATING ENERGY (BTU)

SYSOPE $=$ HOPE + HWOPE + CSOPE

AUXILIARY THERMAL ENERGY TO LOADS (BTU)

AXT = HAT + HWAT

AUXILIARY ELECTRICAL ENERGY TO LOADS (BTU)

AXE $=$ HWAE + HAE ,

SOLAR ENERGY TO LOAD SUBSYSTEMS (BTU)

SEL = HWSE + HSE

ECSS SOLAR CONVERSION EFFICIENCY

CSCEF $=$ CSEO/SEA 
TOTAL ELECTRICAL ENERGY SAVINGS (BTU)

TSVE = HWSVE + HSVE - CSOPE

TOTAL ENERGY CONSUMED (BTU)

TECSM = SYSOPE + AXE + SECA

SYSTEM PERFORMANCE FACTOR

SYSPF $=S Y S L /(A X E+A X T+S Y S O P E) \times 3.33$ 
APPENDIX C

LONG-TERM AVERAGE WEATHER CONDITIONS 
APPENDIX C

LONG-TERM AVERAGE WEATHER CONDITIONS

The environmental estimates given in this appendix provide a point of reference for evaluation of weather conditions as reported in the Monthly Performance Assessments and Solar Energy System Performance Evaluations issued by the National Solar Data Program. As such, the information presented can be useful in prediction of long-term system performance.

Environmental estimates for this site include the following monthly averages: extraterrestrial insolation, insolation on a horizontal plane at the site, insolation in the tilt plane of the collection surface, ambient temperature, heating degree-days, and cooling degree-days. Estimation procedures and data sources are detailed in the following paragraphs.

The preferred source of long-term temperature and insolation data is "Input Data for Solar Systems" (IDSS) [1] since this has been recognized as the solar standard. The IDSS data are used whenever possible in these environmental estimates for both insolation and temperature related sources; however, a secondary source used for insolation data is the climatic Atlas of the United States [2], and for temperature related data, the secondary source is "Local Climatological Data" [3].

Since the available long-term insnlation data are nnly given for a horizontal surface, solar collection subsystem orientation information is used in an algorithm [4] to calculate the insolation expected in the tilt plane of the collector. This calculation is made using a ground reflectance of 0.2 . 
SITE: CONTEYD, SYS.

ANALYST: R. MANDT

COLLECTOR TILT: $\quad 45.00$ (DEGREES)

LATITUDE: $\quad 33.65$ (DEGPEES)
LCCATION: NEWINAN

GA

FOP.IVE NO.: 71 .

COLLECTOR AZIMUTH: 0.0 (DEGPEES)

RUN DATE: 02109179

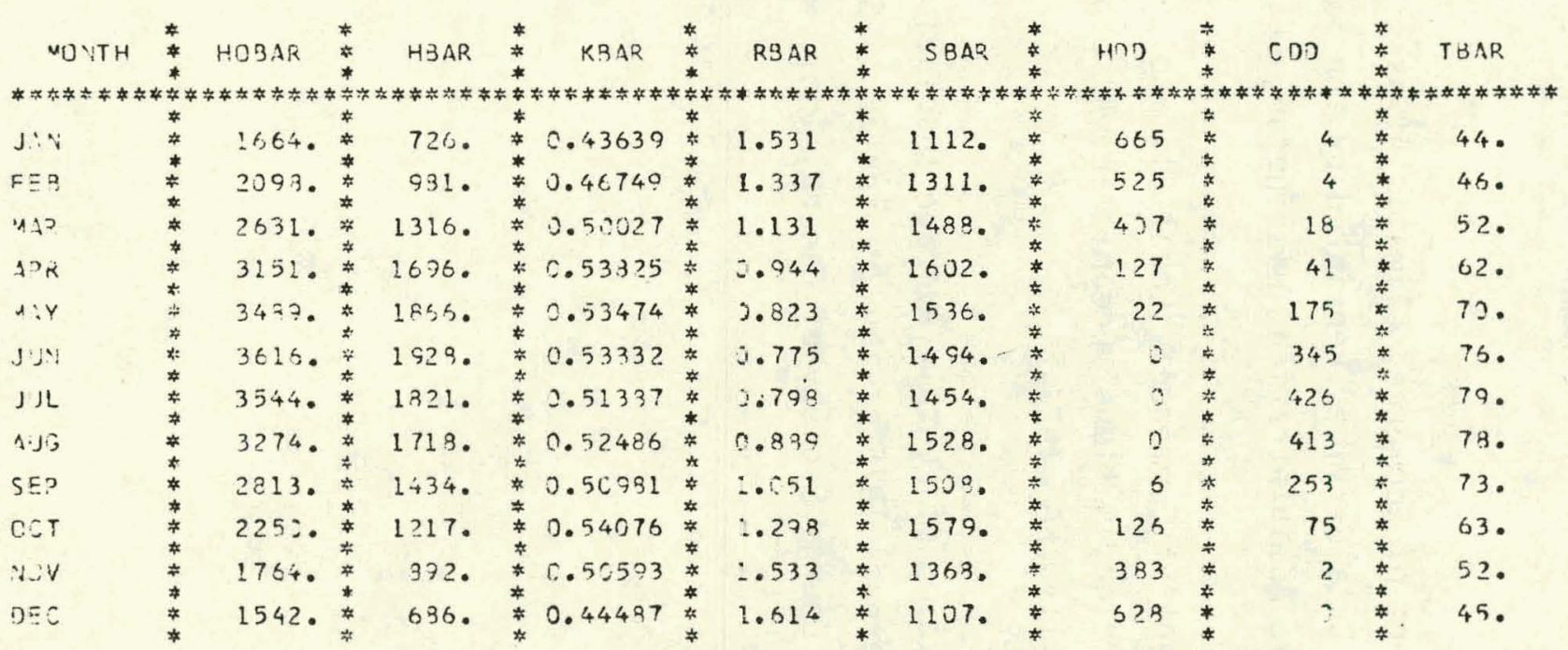

LSGEND:

HOBAR $\Rightarrow$ MONTHLY AVERAGE DAILY EXTRATERRESTRIAL RADIATION (IDEAL) IN $3 T$ TJ/DAY-FT2.

$H B A R \Rightarrow$ MOINTHLY AVER AGE DAILY RADIATION (ACTIIAL) IN BTUIDAY-FT2.

KBAR $\Rightarrow$ RATIO CF HBAR TO HOBAR.

RBAR $\Rightarrow$ RATIO CF MCNTHLY AVERAGE DAILYPADIATIDN DN TILTED SURFACE TO THAT ON A

SBAP $\Rightarrow$ MONTHLY AVERAGE DAILY RADIATION ON A TILTED SURFACE (I.F., RBAR * HRAPI IN BTU/DAY-FT2.

HOD $\Rightarrow$ NUMEER OF HEATING DEGREE DAYS PER MONTH.

CDD $\Rightarrow$ NUMBER OF CODLING DEGREE DAYS PER MUNTH.

TBAP. $\Rightarrow$ AVERAGE AMBIENT TEMPERATURE I V DEGREES FAHRENHEIT. 


\section{REFERENCES}

[1] Cinquemani, V., et a1. "Input Data for Solar Systems." Prepared for the U.S. Department of Energy by the National Climatic Center, Asheville, NC, 1978.

[2] United States Department of Commerce, Climatic Atlas of the United States, Environmental Data Service, Reprinted by the National Oceanic and Atmospheric Administration, Washington, DC, 1977.

[3] United States Department of Commerce, "Local Climatological Data," Environmental Data Service, National Oceanic and Atmospheric Administration, Asheville, NC, 1977.

[4] Klein, S. A., "Calculation of Monthly Average Insolation on Tilted Surfaces," Joint Conference 1976 of the International Solar Energy Society and the Solar Energy Society of Canada, Inc., Winnipeg, August $15-20,1976$. 